\title{
Sustentabilidade urbana aplicada: Análise dos processos de dispersáo, densidade e uso e ocupaçáo do solo para a cidade de Cuiabá, Estado de Mato Grosso, Brasil ${ }^{1}$
}

Geovany Silva. Universidade Federal da Paraíba, João Pessoa, Brasil.

Marta Romero. Universidade de Brasília, Brasília-DF, Brasil.

RESUMO | Investigar o conceito de urbanismo sustentável é o objetivo principal desta pesquisa, bem como seus possíveis procedimentos metodológicos e aplicaçóes, estas últimas definidas a partir da análise urbana para a cidade de Cuiabá, capital do Estado de Mato Grosso, Brasil. Nos países em desenvolvimento, as cidades ganharão mais de 2 bilhóes de habitantes para os próximos 30 anos, condicionando essas regióes a sérios impactos ambientais e socioeconômicos, entre outros efeitos nefastos para o convívio humano e à qualidade de vida, pois mais da metade dessas pessoas será relegada às favelas e ocupaçóes irregulares. O Brasil crescerá em quase 30 milhóes de habitantes nos próximos 30 anos, destes, a grande maioria habitará as cidades. Assim, esta pesquisa busca apresentar os caminhos alternativos à urbanidade vigente que, por meio de análises aplicadas qualitativas e quantitativas entre 2000 e 2010, resultaram no entendimento da condiçáo urbana de Cuiabá e seu processo de dispersão (escala urbana), uso e ocupação (escala de 25 ha).

PALAVRAS-CHAVE | urbanismo sustentável; expansão urbana; sistema urbano; planejamento urbano; meio ambiente urbano.

ABSTRACT | The main objective of this research is to investigate the concept of sustainable urbanism, both in terms of methodological processes and possible applications. The latter will be defined based on an urban analysis of the city of Cuiaba, the capital of Mato Grosso State in Brazil. In developing countries, cities will grow by over 2 billion people over the next 30 years, a process that implies serious environmental and socioeconomic impacts in these urban regions, among other adverse effects on human society and quality of life, as over half of the emerging population will be relegated to living in slums and illegal occupations. Brazil will grow by nearly 30 million people over the next 30 years, and the vast majority of this population will live in cities. This research seeks to provide alternative paths to current urban processes. These alternatives are supported by the qualitative and quantitative analyses applied between 2000 and 2010, which have allowed for a better understanding of the urban condition of Cuiabá regarding its population dispersion process (on an urban scale), as well as land use and occupation (on a scale of $25 \mathrm{ha}$ ).

KEYWORDS | urban sustainability; urban sprawl; urban system; urban planning; urban environment.

Recibido el 2 de diciembre de 2012, aprobado el 7 de octubre de 2013

E-mail: galexarq@gmail.com | bustosromero@gmail.com

Correspondencia autor principal: Universidade Federal da Paraíba, Av. Cabo Branco, No 3092, Apto 220, Edif. Atlântico Sul, Joăo Pessoa, CEP: 58.045.010, Brasil.

1 Este artigo é um resumo da Tese de Doutorado intitulada "Cidades sustentáveis: uma nova condição urbana. Estudo de Caso: CuiabálMT”, orientada pela Profa. Marta Romero. Ver: http://www.capes.gov. br/images/stories/download/legislacao/portaria-n-160-20112012-PremioCapesdeTeseEdicao2012.pdf. 


\section{Introduçáo}

A necessidade de se estabelecer novas formas e métodos de investigação, interpretação, monitoramento e aplicaçóes espaciais ao planejamento urbano e regional, integrado e sustentável se faz cada vez mais evidente para o mundo urbano atual, de mais de 3,5 bilhóes de pessoas em escala global e, para o universo urbano brasileiro, este com mais de 160 milhóes de habitantes partícipes da cidade, de um total de 190 milhóes de pessoas. O Brasil já concentra mais de $80 \%$ de sua população em suas cidades e estima-se que para os próximos 30 anos, agregará mais de 30 milhóes de pessoas, majoritariamente, nas áreas urbanas.

Este processo de urbanização se deu entre as décadas de 1940 e 1980, período no qual o Brasil assiste a um fenômeno de inversão quanto ao habitat da população. Se em 1940 a taxa de urbanização era de 26,35\% da população total, em 1980 chega a $68,86 \%$. Neste período, a população do país triplica, ao passo que a população urbana multiplica-se por sete vezes e meia (Santos, 2009, p. 31). No período mais recente, se em 1991 a populaçáo total urbana era de 77\%, entre os 146.825 .475 habitantes, em 2000 esse percentual já ultrapassa a casa dos $80 \%$ dos 169.799 .170 habitantes (Confederação Nacional dos Municípios [CNM], 2010). As projeções demográficas apontam para 219,1 milhóes de habitantes em 2039 - ponto máximo da curva demográfica -, e 215,3 milhóes em 2050 (Instituto Brasileiro de Geografia e Estatística [IBGE], 2008, p. 28).

No período de 2002 a 2007, a população em cidades médias brasileiras cresceu à taxa de $2 \%$ ao ano, mais que as taxas das cidades grandes $(1,66 \%)$ e das cidades pequenas $(0,61 \%)$. Do ponto de vista populacional, as cidades grandes e pequenas encolheram entre 2000 e 2007, enquanto as médias cresceram. As cidades médias concentravam 23,8\% da populaçáo em 2000 e passaram a 25,05\% em 2007. As grandes aglomeraçóes urbanas caíram de $29,81 \%$ para $29,71 \%$ da população urbana total, e as pequenas, de $46,39 \%$ para $45,24 \%$, no mesmo período (Instituto de Pesquisa Econômica Aplicada [IPEA], 2008). Assim, esses fatores reforçam a necessidade de se investigar os processos urbanos em cidades médias brasileiras, como polos atrativos de capital, oportunidades e pessoas, bem como as projeçóes de cenários para o planejamento.

Houve, essencialmente após a década de 1970, uma interiorização do crescimento demográfico e desenvolvimento socioeconômico, o que Santos (2009) denominaria de fenômeno da desmetropolização brasileira (ou a "dissolução da metrópole"). Dentre os diversos fatores que imperam nesse processo, está a especulação do capital transnacional e o avanço da fronteira agroindustrial sobre o interior do país a partir de incentivos da política nacional de interiorização do desenvolvimento e da ocupação - especialmente sobre as regiōes Centro-Oeste e Norte. A busca por regióes pouco exploradas, de recursos abundantes, mão-de-obra e terra barata, conectadas cada vez mais por uma logística de infraestrutura e configurada por redes, são as condicionantes decisivas para a dinamização das economias do interior do Brasil, levando junto ao avanço da agricultura, investimentos e capitais de toda a cadeia agroindustrial. Assim, entende-se que esses processos urbanos descritos têm impactos decisivos, na forma de se constituir e planejar as cidades brasileiras. 
Deste modo, esta pesquisa propóe um estudo aplicado acerca das "cidades sustentáveis" como uma "nova condiçấo à urbanidade contemporânea", perfazendo publicaçôes, revisitando conceitos, reposicionando paradigmas, reinterpretando utopias e apresentando novas expressóes locais para cidades brasileiras e latino-americanas. Para tanto, se utiliza da aplicaçáo de estudo de caso para a cidade de Cuiabá, capital do Estado de Mato Grosso, Brasil, que apresenta atualmente 541 mil habitantes e se conurba à cidade de Várzea Grande, englobando uma população urbana aproximada de 790 mil habitantes em 2010 (IBGE, 2010). A partir de então, se formulou a hipótese de que há recorrência da dispersão urbana de baixa densidade em CuiabáMT na última década devido aos processos de planejamento urbano e regional configurados. (Fig. 1)

\section{Figura 1 | A localização do Estado de Mato Grosso e a capital Cuiabá no contexto brasileiro e latino-americano}

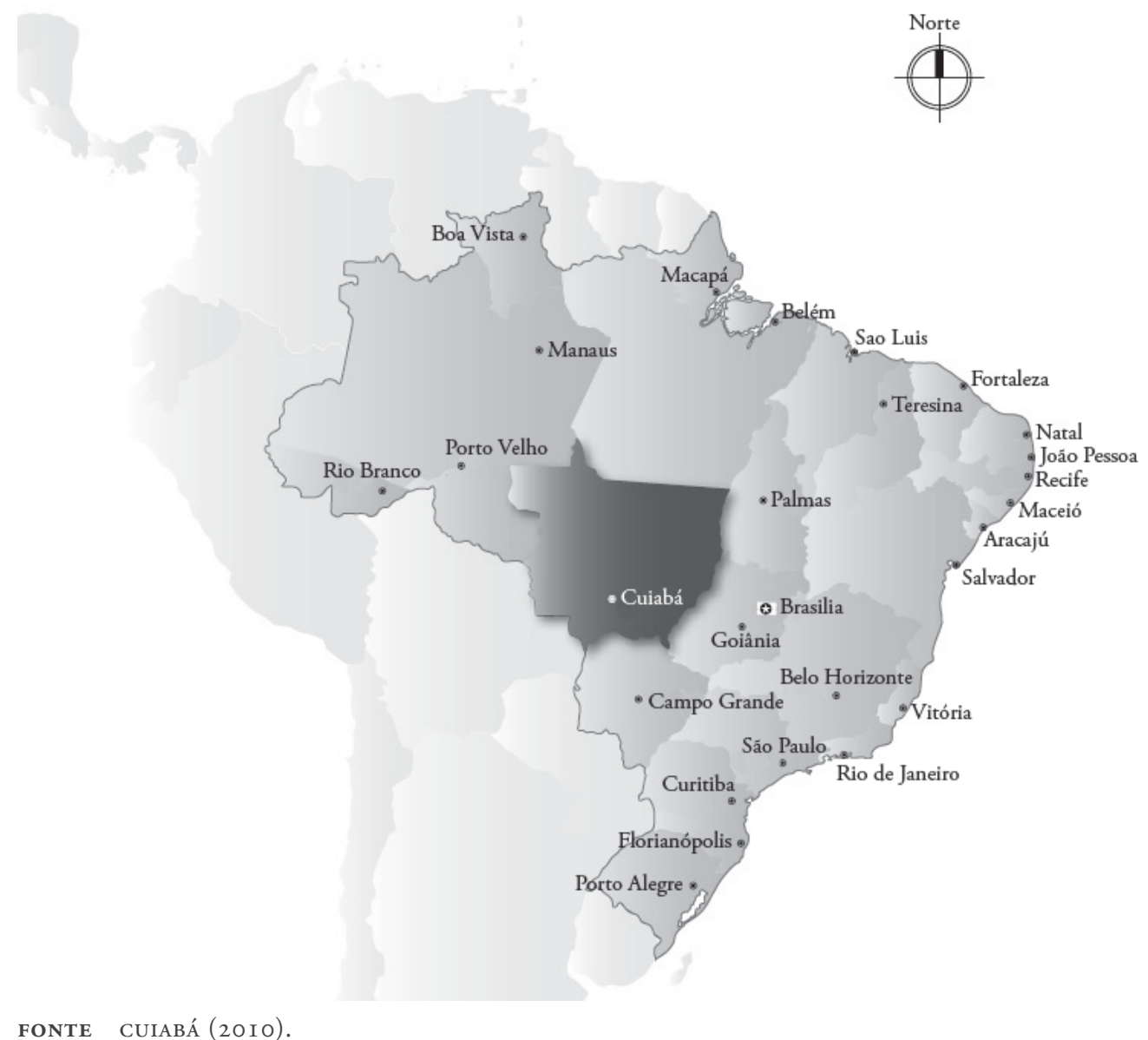

Assim, o objetivo geral da pesquisa se centrou em realizar, num primeiro momento, nos estudos de abordagem teórica sobre a sustentabilidade urbana no aspecto global (internacional e nacional) para, posteriormente, aplicar análises à cidade de Cuiabá, por meio de procedimentos metodológicos desenvolvidos. Em decorrência disso, os objetivos específicos se traduziram em compreender conceitos de sustentabilidade 
urbana, bem como métodos de avaliação e, ao final aplicar, em um estudo de caso específico para Cuiabá-MT, os processos apreendidos neste campo do urbanismo durante o trabalho investigativo.

A seleção da cidade de Cuiabá como estudo de caso, deu-se em decorrência da necessidade de aplicação dos conceitos e teorias analisados, bem como da investigaçáo metodológica por meio de escalas de análise urbana (macro, meso e micro-escala), a ser experimentada para uma cidade de porte médio que exerça um papel de metrópole regional. Desta forma a capital mato-grossense, como metrópole de porte médio de grande dispersão e crescimento demográfico pós 1970, também apresenta problemas recorrentes na maioria das cidades brasileiras, cujo planejamento urbano tornou-se fragmentado em relação ao território e de pouca articulação técnica e conceitual. Cuiabá também está numa região de reduzidas pesquisas no campo do urbanismo e planejamento, o que torna a investigação um desafio passível de inovação e contribuição social para a regiáo. Destacaram-se fatores recorrentes à realidade urbana de Cuiabá que justificam a sua escolha como objeto de pesquisa:

1. A condição climática desfavorável da cidade, decorrente da localização do sítio urbano em uma área de depressáo - a baixada cuiabana - com baixa velocidade de vento, altas temperaturas (média anual de $32^{\circ} \mathrm{C}$, com máx. de $41^{\circ}$ e mín. de $\left.16,6^{\circ} \mathrm{C}\right)$, reforçando a influência da massa edificada sobre o microclima da cidade (Centro de Previsão de Tempo e Estudos Climáticos / Instituto Nacional de Pesquisas Espaciais [CPTEC/InPE], 2010);

2. A localização urbana em área tropical continental, de clima quente-seco de junho à agosto, e quente-úmido de setembro à maio, faz com que sejam identificadas grandes interferências do uso e ocupação do solo na formação de ilhas de calor em Cuiabá (Maitelli, 1994; Duarte \& Serra, 2003, p. 11; Silva, 2010, p. 240);

3. A diversidade morfológica da cidade, resultante de uma sobreposição de "camadas urbanas" ao longo do tempo, caracterizando um centro antigo do século XVIII às novas roupagens da modernização e desenvolvimento, até culminar numa capital de grande influência regional a partir da década de 1970, firmando-se como polo de setores secundários e terciários nas últimas duas décadas (Silva, 2010, p. 240);

4. As questóes ambientais de relevância, pois a cidade está numa área de intensidade hídrica, com afloramento de centenas de nascentes e dezenas de córregos na área urbana, sendo cortada pelo rio Coxipó e rio Cuiabá, sendo este último, uma importante bacia hidrográfica regional. Por outro lado, a capital e a região é carente de estudos de sustentabilidade urbana aplicada;

5. A localização numa área de sobreposição de biomas, sendo identificados aspectos ambientais característicos do Bioma Pantanal, como também do Bioma Cerrado, o que coloca em risco a biodiversidade por meio da urbanizaçáo dispersa e da invasão de áreas de preservação ambiental;

6. A intensa dispersão urbana vivenciada a partir da década de 1970 condicionou a capital a uma conurbação com a cidade de Várzea Grande, configurando um aglomerado urbano de 789,8 mil habitantes (IBGE, 2010) e com mais de 98\% 
da população em área urbana. Esse fenômeno de crescimento e urbanização reproduziu desigualdades socioespaciais, invasóes, periferização, violência, características estas típicas de grandes cidades latino-americanas, e que tenderão a se intensificar nas décadas futuras, aumentando o quadro de degradação e conflito regional;

7. Os prognósticos futuros apontam para uma capital de mais de um milhão de habitantes em 2025 (un-Habitat, 2008, p. 245), num Estado de intenso crescimento econômico e que, por sua importância regional, foi eleita como uma das cidades-sedes da Copa do Mundo de Futebol em 2014. Esse fato determinará o futuro urbano e a qualidade de vida da capital para os próximos anos, tendo em vista a atração de investimentos para a cidade e a visibilidade internacional da capital. Potencializar esses investimentos poderá alterar a dinâmica urbana, social, econômica e ambiental da cidade, como também, do contrário, acentuará ainda mais as crises urbanas e condicionará problemas ainda maiores para as próximas décadas.

As rotinas de pesquisa se sustentam sobre algumas etapas metodológicas inseridas no contexto da abordagem sistêmica integrada, desenvolvidas por meio de pesquisas junto ao Laboratório de Sustentabilidade Aplicada à Arquitetura e Urbanismo (Lasus) $^{2}$ da Faculdade de Arquitetura e Urbanismo da Universidade de Brasília (FAUUnB). Assim, transcorreram-se as seguintes fases de trabalho:

a. Fundamentação Teórica: Pesquisa sobre cidades e projetos urbanos pregressos a partir do século xx;

b. Estudos de Caso com Experimentos Urbanos Sustentáveis Analisados por Escalas: Propostas das últimas décadas, a partir das recentes pesquisas científicas; Foram adotadas as escalas de análise de sistemas urbanos (macro, meso e micro), seguindo-se os seus respectivos contextos e áreas de influências;

c. Procedimento metodológico norteador (abordagem sistêmica): Viés investigativo (qualitativo e quantitativo); Viés propositivo (dedutivo e indutivo). Ambos geradores do produto de análise urbana.

d. Respostas e Apontamentos para o Futuro:

d.1 Quantitativos: Estudos sobre a dispersão urbana em Cuiabá-MT; Análise de 12 parcelas urbanas de 25 ha em Cuiabá-MT.

d.2 Qualitativos: Quadro de Efeitos do Espalhamento Urbano em Cuiabá-MT (Social, Econômico, Ambiental, Político, Gestão e Urbano).

A presente pesquisa descrita e resumida neste artigo é resultante da tese de doutorado defendida em dezembro de 2011 junto ao PPG-FAU-UnB ${ }^{3}$, intitulada "Cidades Sustentáveis: uma nova condição urbana. Estudo de caso: Cuiabá-MT", sob a orientação da Profa. Dra . Marta Romero. Para tanto, buscou-se a compreensão dos fenômenos urbanos das últimas décadas, associando-se às teorias e métodos de análise urbana aplicada à sustentabilidade, como foco de pesquisa geradora do produto (a tese).

LaSUS-FAU-UnB, disponível em: http://www.lasus.unb.br/.

3 Programa de Pesquisa e Pós-Graduação da Faculdade de Arquitetura e Urbanismo, Universidade de Brasília (Disponível em: http://www.fau.unb.br/index.php/pos-graduacao). 
Diretrizes gerais para o futuro urbano sustentável: conceitos e métodos

Associar a noçáo de sustentabilidade à arquitetura e ao urbanismo torna-se um desafio expressivo, pois quando se pensa em alteração da matéria natural em espaço edificado e, consequentemente, constituindo-se cidades, há uma dissociação espontânea entre o natural e o artificial, face às necessidades humanas de habitat e abrigo para os eventos de sua vida e sociedade. Assim como se compreende a antítese de desenvolvimento sustentável, tendo em vista a dicotomia conceitual de ambas as palavras (já que a primeira - o desenvolvimento - subentende um aspecto economicista, de crescimento, progresso; e, a segunda - o sustentável - refere-se à permanência, equilíbrio, equidade, o que é sustentado e tem condiçóes próprias de se manter independentemente, e igualmente, seria o desenvolvimento sustentável?), pode-se tranquilamente pensar na antítese de arquitetura sustentável e do urbanismo sustentável. Náo obstante os avanços tecnológicos, a difusão do conhecimento e da conscientização ambiental, bem como as recentes projeçóes demográficas caminhando para a estabilidade apontam para uma perspectiva mais positiva e coerente no sentido de sustentabilidade da espécie humana para o futuro, fazendo coexistir o conceito de progresso bumano sustentável ou constituição de modus vivendis menos insustentáveis.

A sustentabilidade urbana deve propor novas formas de apropriação do espaço, condizentes com as necessidades emergenciais apresentadas à sociedade global hoje, e coerentes com a sinergia e equidade entre as esferas sociais, ambientais, econômicas e de governança; em conformidade com o quadripé da sustentabilidade. (Fig. 2).

FIGURA 2 Evoluçáo do conceito de sustentabilidade (quadripé da sustentabilidade) a partir da inserçáo da "Governança" integrada aos aspectos social, econômico e ambiental (antigo conceito do tripé ${ }^{4} \mathrm{da}$ sustentabilidade).
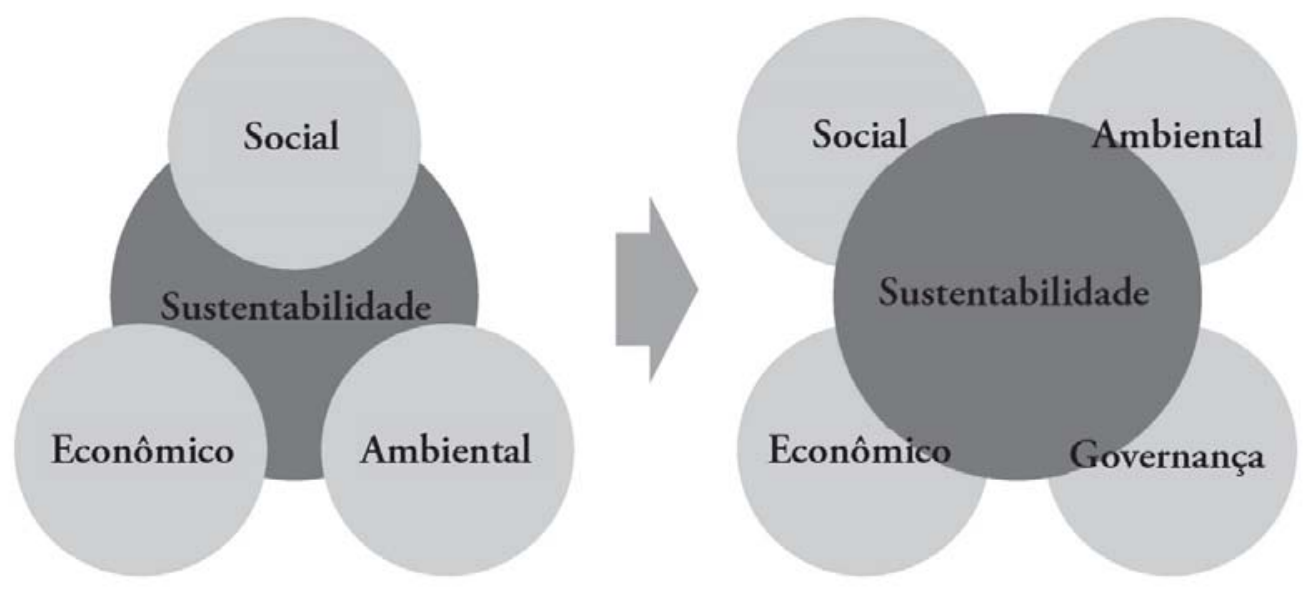

FONTE ELABORAÇÃ̃o PRÓPRIA (20I4).

4 Tripé da Sustentabilidade (ou Triple Botton Line) é a teoria que define que não se alcança o desenvolvimento sustentável melhorando ou priorizando políticas em apenas uma, ou duas, das três esferas citadas: a social, a econômica e a ambiental (Elkington, 1999). 
Autores como Rueda (2002), Rogers e Gumuchdjian (2001), Girardet (1997), Kennedy, Cuddihy e Engel-Yan (2007), Novotny (2010), Wolman (1965), entre outros, e suas respectivas teorias, apontam possíveis soluçóes, ou minimização, aos problemas dos impactos ambientais das cidades contemporâneas a partir da implementação de um 'metabolismo' circular para o urbano, propondo assim uma redução considerável do consumo por meio de aplicaçôes tecnológicas ambientais, mudança de hábitos e promoção de um programa de educação ambiental efetivo, redução de resíduos e poluentes, estabilização demográfica, promoção eficaz de um sistema de reutilização de recursos e energia.

Sobre os aspectos referentes ao metabolismo urbano, a cidade compacta se traduz num sistema circular, com menor impacto no sistema-entorno, em contraposição ao modelo urbano de cidade difusa, de metabolismo linear de maior entrada de energia e recursos, como também maior poluição e impacto ambiental (Figs. 3 e 4). Essa antítese conceitual fornece uma importante ferramenta de análise morfológica da cidade, sendo possível apontar as características específicas das particularidades urbanas conforme o modelo de urbanização adotado pela gestão regional, constituindo-se territórios de densidades variáveis e de impactos diversificados conforme o agrupamento ou distanciamento de suas partes e funçóes.

\section{FIgURA 3 | Diagrama de cidades com metabolismo linear que consomem e poluem em maior volume}

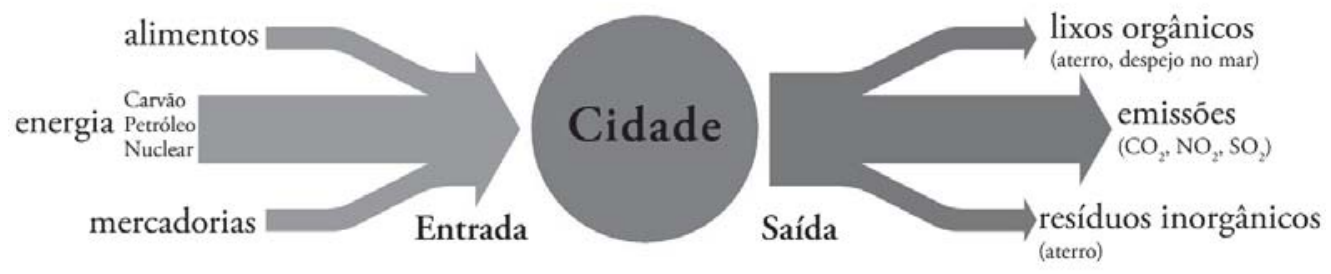

FONTE ELABORAÇÃo PRÓPRIA (20I I) ADAPTAdo DE ROGERS (2005, P. 3 I).

Em síntese, o urbanismo sustentável prima pela diversidade de usos e funçóes sobrepostos em um tecido denso e compacto, porém, que respeite as condicionantes geográficas e ambientais locais e regionais, bem como as escalas e proporçóes adequadas de apropriação do espaço público e privado. O lugar, o particular, a identidade cultural e as especificidades sáo alguns dos principais atributos que devem estar presentes na urbe do futuro, esta que reconhece o sentido de comunidade, a urbanidade, o ambiente, a otimizaçáo energética e uso de recursos. A cidade sustentável é democrática e participativa, volta-se ao regional, compreende a morfologia a partir da lógica evolutiva e estruturada para o crescimento orgânico e em conformidade com o sistema-entorno equilibrado. 
FIGURA 4 | Diagrama de cidades com metabolismo circular, que minimizam a entrada de energia, recursos e materiais, ao passo que reduzem substancialmente a produção de resíduos e poluiçáo

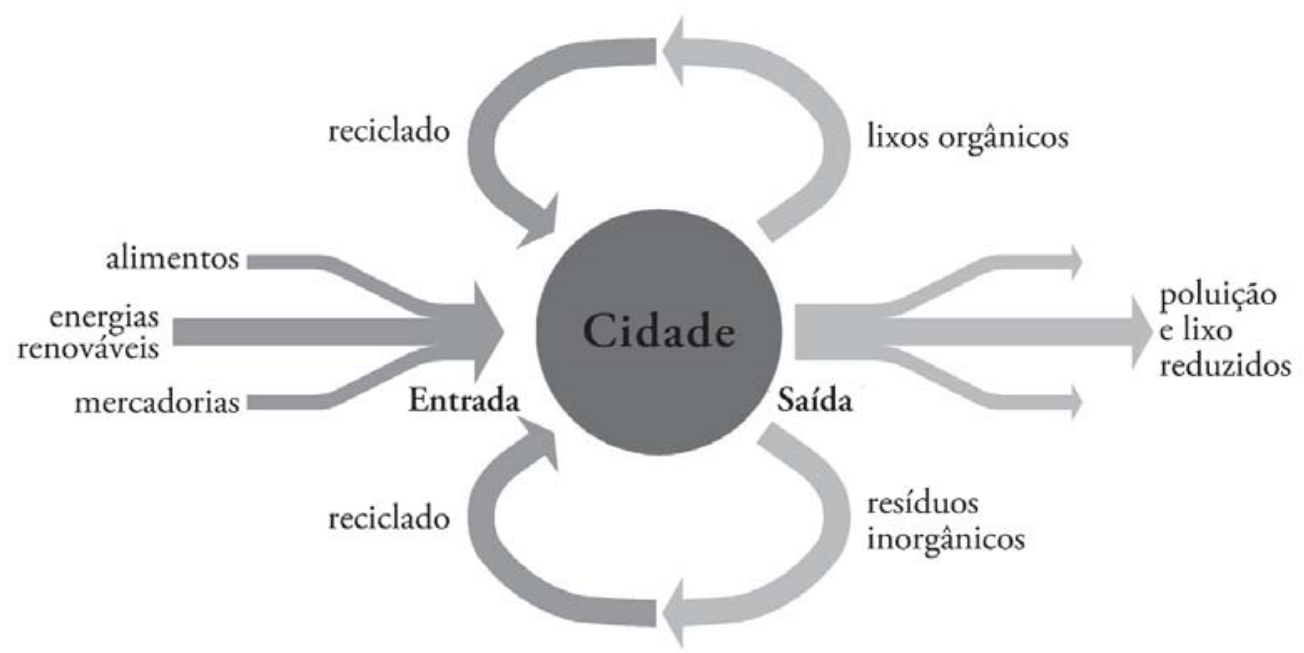

FONTE ELABORAÇÃo PRÓPRia (20I I) ADAPTADO DE ROGERS (2005, P. 3 I).

Os projetos urbanos sustentáveis obedecem à percepção das escalas (em especial, à humana e pedonal), sustentando as funçóes vitais, restabelecendo o sentido e orientação no tempo-espaço, face à necessária adequação aos habitantes, seus usos e equipamentos. Entende-se que a compacidade urbana deve ser adotada como configuração espacial e legal, eliminando-se os vazios urbanos (e aplicando de fato as ferramentas legais existentes nos respectivos Planos Diretores municipais), encurtando distâncias para o pedestre, aumentando a coesão social, minimizando a dependência de automóveis individuais (com ênfase ao transporte coletivo). Porém, o nível de compacidade deve respeitar as condicionantes locais (clima, topografia, cultura, meio ambiente, morfologia, etc.), e, assim, ser determinado por meio de parâmetros resultantes de pesquisas urbanísticas específicas, testes e simulaçóes de intensidade ocupacional edificada (otimizando usos, equipamentos comunitários e infraestrutura) aplicadas caso-à-caso, e não seguindo padróes genéricos como são as ferramentas legais rígidas aplicadas nas cidades brasileiras sob a determinação de políticas nacionais do Ministério das Cidades. (Fig. 5)

A legislação deve ser flexível no sentido de se adequar às mudanças morfológicas da cidade, os agentes de planejamento e às atuaçóes do mercado imobiliário (agentes econômicos e especulativos), pois, segundo Bertaud (2004), é essencial que os planejadores monitorem as estruturas urbanas de forma consciente em relação às tendências espaciais, e que conheçam as limitaçóes impostas pela atual estrutura de opçóes políticas. (Fig. G) 
FIGURA 5 | Diagrama-síntese acerca dos aspectos contribuintes para a sustentabilidade urbana.

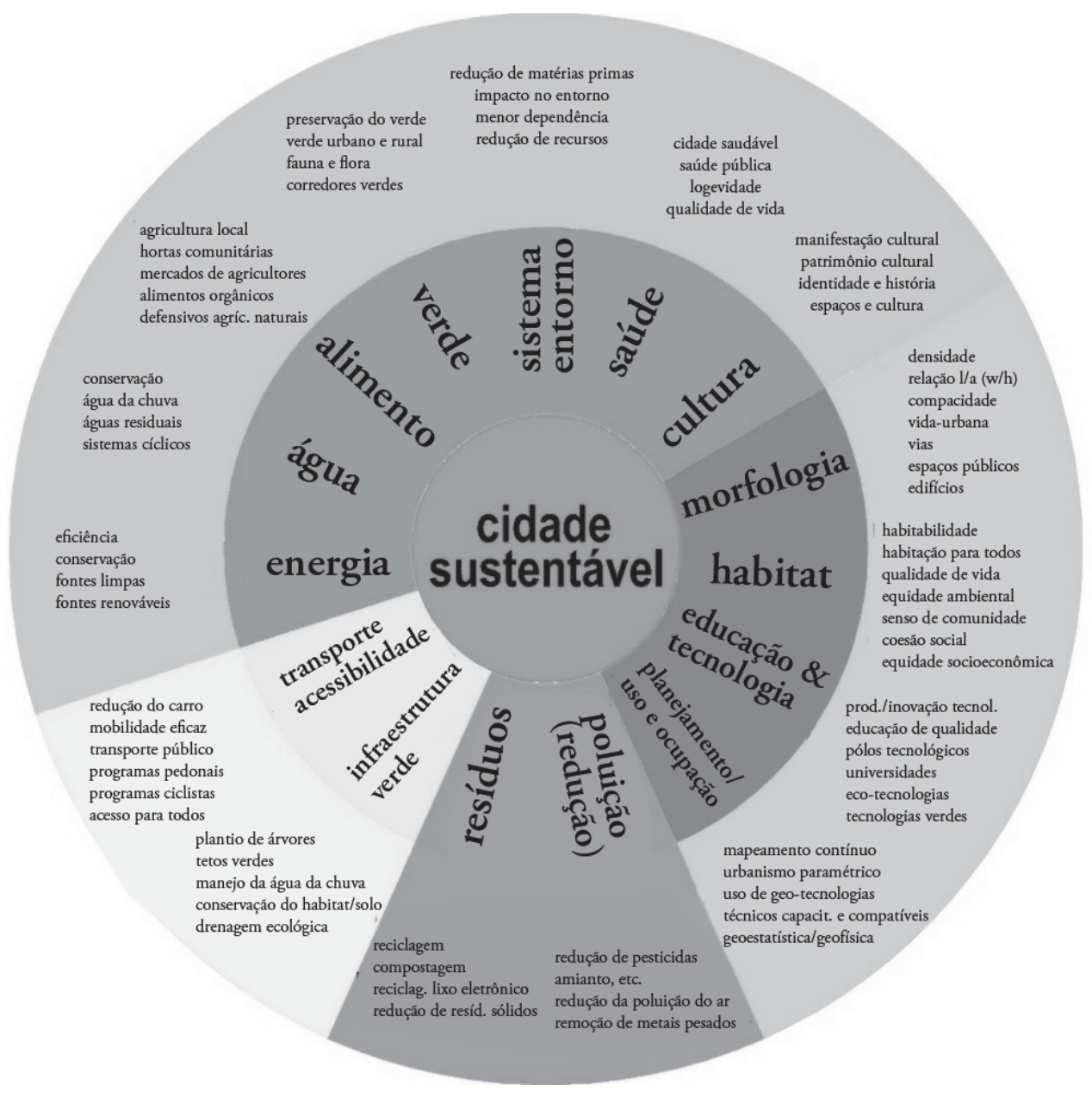

FONTE ELABORAÇÃo PRÓPRIA (20I4).

A partir da pesquisa sobre as teorias e modelos urbanos para o planejamento da sustentabilidade das cidades, compreendeu-se, quanto aos aspectos qualitativos, as desvantagens morfológicas de uma cidade de baixa densidade e dispersa conforme suas conexóes urbanas, identidade e percepção ambiental, morfologia e meio ambiente. Em resumo, distintos aspectos avaliados apontam para um predomínio do modelo compacto sobre o disperso, quanto à tessitura urbana. Num país que cresce para o interior (movimento este cada vez mais acentuado nas últimas décadas e com o avanço do agronegócio), e com novas demandas sociais, econômicas, ambientais, territoriais e urbanas, planejar as cidades à caminho do oeste do território nacional se torna emergencial, face aos impactos ambientais que se prenunciam para o futuro e que certamente atingirão o país em suas diversas partes. Assim, a seguir, será descrita a análise da dispersão urbana recorrente na cidade de Cuiabá-MT, quantitativa e qualitativa, como procedimento metodológico para identificação dos fenômenos urbanos de espalhamento e uso e ocupação do solo em parcelas reduzidas da cidade. 
FIGURA 6 | Interaçóes entre Forças de Mercado e Ação Governamental sobre a estrutura espacial da cidade

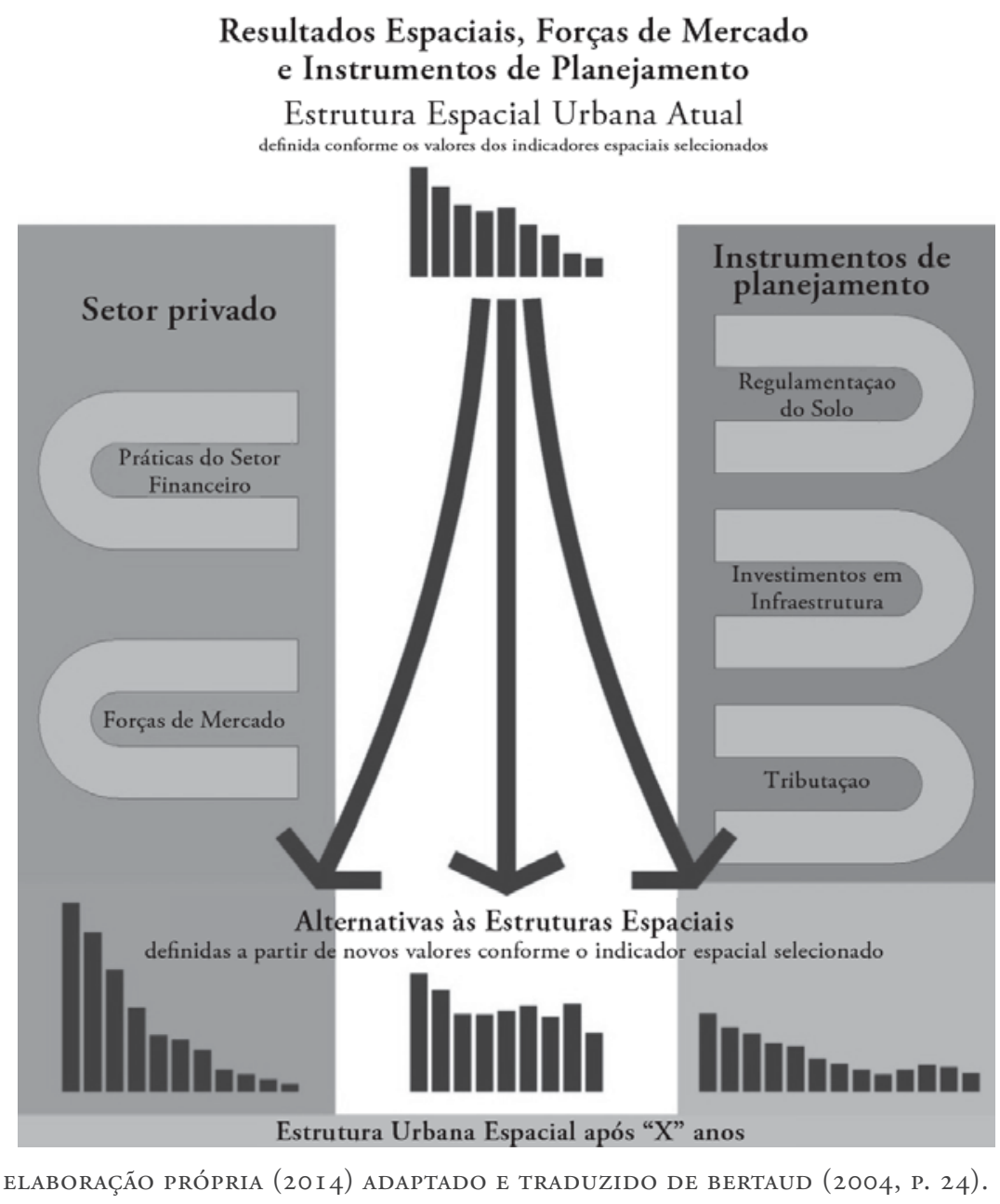

FONTE ELABORAÇÃo PRÓPRIA (20I4) ADAPTAdo E TRADUZido DE BERTAUd (2004, P. 24 ).

O fenômeno da dispersão urbana e conjecturas: Análise quanti-qualitativa aplicada à Cuiabá-MT

Apesar dos critérios estabelecidos pelo IBGE determinarem que a cidade de Cuiabá seja a única cidade brasileira com mais de 500 mil habitantes a náo possuir favelas, por outro lado, são muitos os bairros, como o "Altos da Serra", que não possuem infraestruturas mínimas, pois a maior parte desses bairros não tem asfalto, água, esgoto e a rede de iluminação pública é mínima. Em 2008, estimava-se que o déficit habitacional na capital ultrapassava o montante de 26 mil casas - em 2003, a estimativa de déficit era de 10 mil habitaçóes - sendo que havia cerca de 5,2 mil famílias morando em assentamentos precários ou em áreas de risco.

A prefeitura municipal deduz que por volta de $60 \%$ dos bairros da periferia não sejam regularizados, o que impede a destinação de recursos federais para a melhoria da infraestrutura e habitação para essas áreas. O crescimento da população no aglomerado urbano Cuiabá - Várzea Grande, nas últimas décadas, tem sido fator predominante para a intensificação da crise habitacional e periferização na região. (Fig. 7) 
Em Cuiabá o fenômeno da dispersão urbana invadiu um território extenso na última década, o que eram 9.202 ha em 2000, dez anos depois já eram mais de 13.422 ha mapeados nesta pesquisa. Assim, enquanto a área urbana avançou $45,86 \%$, a população da cidade cresceu apenas $13,54 \%$, de 476,5 mil habitantes para 541 mil nesse mesmo período, demonstrando que a dispersão urbana tem sido uma realidade expressiva na capital do Estado de Mato Grosso (Ver a Tabela 1). A especulação imobiliária intensa, o acesso a programas habitacionais, a regularização de áreas invadidas, o aumento de recursos habitacionais decorrentes do avanço das condiçóes econômicas regionais, resultantes de uma conjuntura nacional de crescimento na última década, dentre outros fatores, são os responsáveis para a dispersão da cidade edificada.

FIGURA 7 | Gráfico da população/ano no aglomerado urbano Cuiabá - Várzea Grande entre 1890 e 2010

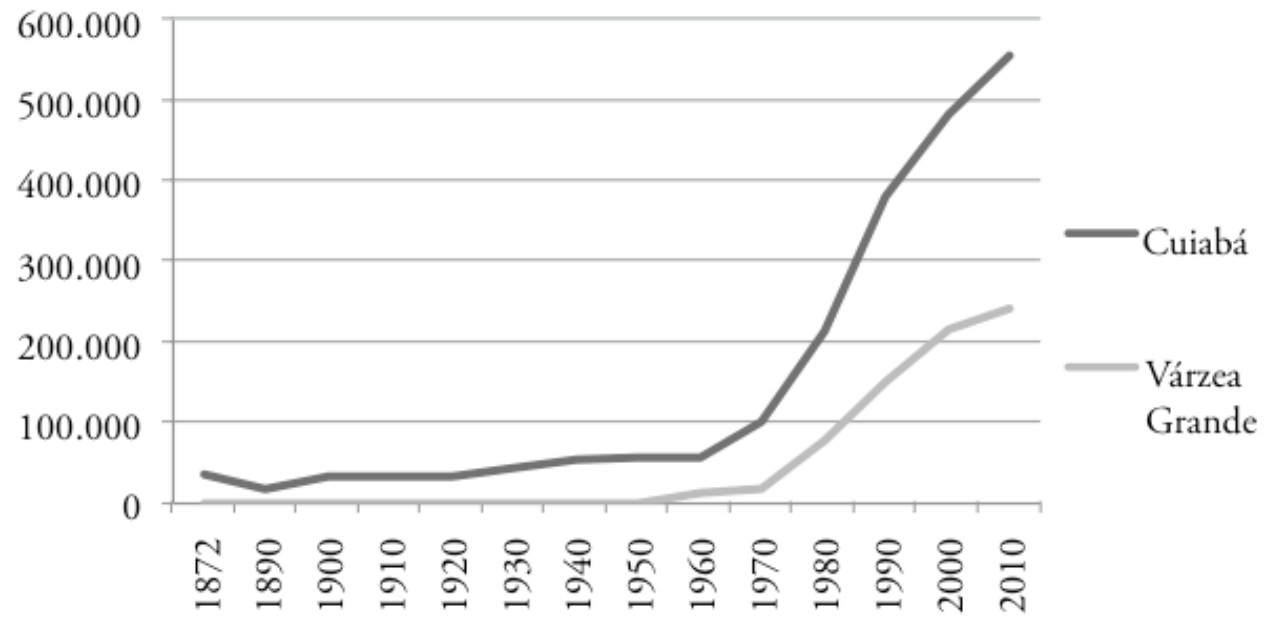

FONTE SILVA (20II, P. 268).

TABELA 1 | As alteraçóes das áreas urbanizadas e não-urbanizadas da área de estudo a partir de imagens entre 2000 e 2010

\begin{tabular}{|c|c|c|c|}
\hline $\begin{array}{c}\text { CLASSE DE COBERTURA } \\
\text { TERRESTRE }\end{array}$ & 2000 & 2010 & $\begin{array}{c}\text { \% DE CRESC. NO } \\
\text { PERÍODO }\end{array}$ \\
\hline \multirow{2}{*}{ Urbanizada } & $92,02 \mathrm{~km}^{2}$ & $134,22 \mathrm{~km}^{2}(* *)$ & \multirow{2}{*}{$45,86 \%$} \\
\hline & $36,40 \%$ & $52,96 \%$ & \\
\hline \multirow{2}{*}{ Não-urbanizada } & $160,83 \mathrm{~km}^{2}$ & $119,24 \mathrm{~km}^{2}$ & \multirow{2}{*}{$25,86 \%$} \\
\hline & $63,60 \%$ & $47,04 \%$ & \\
\hline \multirow{2}{*}{ Total } & $252,86 \mathrm{~km}^{2}(*)$ & $253,46 \mathrm{~km}^{2}$ & \multirow{2}{*}{$0,24 \%$} \\
\hline & $100,00 \%$ & $100,00 \%$ & \\
\hline
\end{tabular}

* área do perímetro urbano de cuiabá; ** em 20 io, cerca de o,6 KM² de ocupação havia INVADIDO UMA ÁREA ALÉM DO PERÍMETRO URBANO LEGALIZADO EM 2000, ÁREA REGULAMENTADA EM 2004 PELA PREFEITURA MUNICIPAL.

FONTE SILVA (20II, P. 27I). 
Na Fig. 8 a seguir é possível notar as áreas que foram tomadas pela invasão urbana na última década, sendo destacado que todas as porçóes urbanas - leste, oeste, norte e sul - tiveram áreas invadidas entre 2000 a 2010. A diminuição da mata nativa de cerrado no entorno, assim como a ocupação de áreas de risco como margens de córregos e regiôes próximas ou dentro do perímetro industrial, são as regiôes preferenciais em virtude da falta de fiscalização do poder público e da disponibilidade de terra barata para esse fim. O impacto ambiental é evidente, ao passo que não se tem infraestrutura adequada, as condiçóes de vida tornam-se críticas para a população que busca viver nas áreas junto aos limites da dispersão urbana.

FIgURA 8 | Quantificação da dispersão urbana na última década em Cuiabá, com aumento de cerca de $46 \%$ na dispersáo urbana em mapeamento a partir de imagens aerofotos e de satélite entre 2000 e 2010

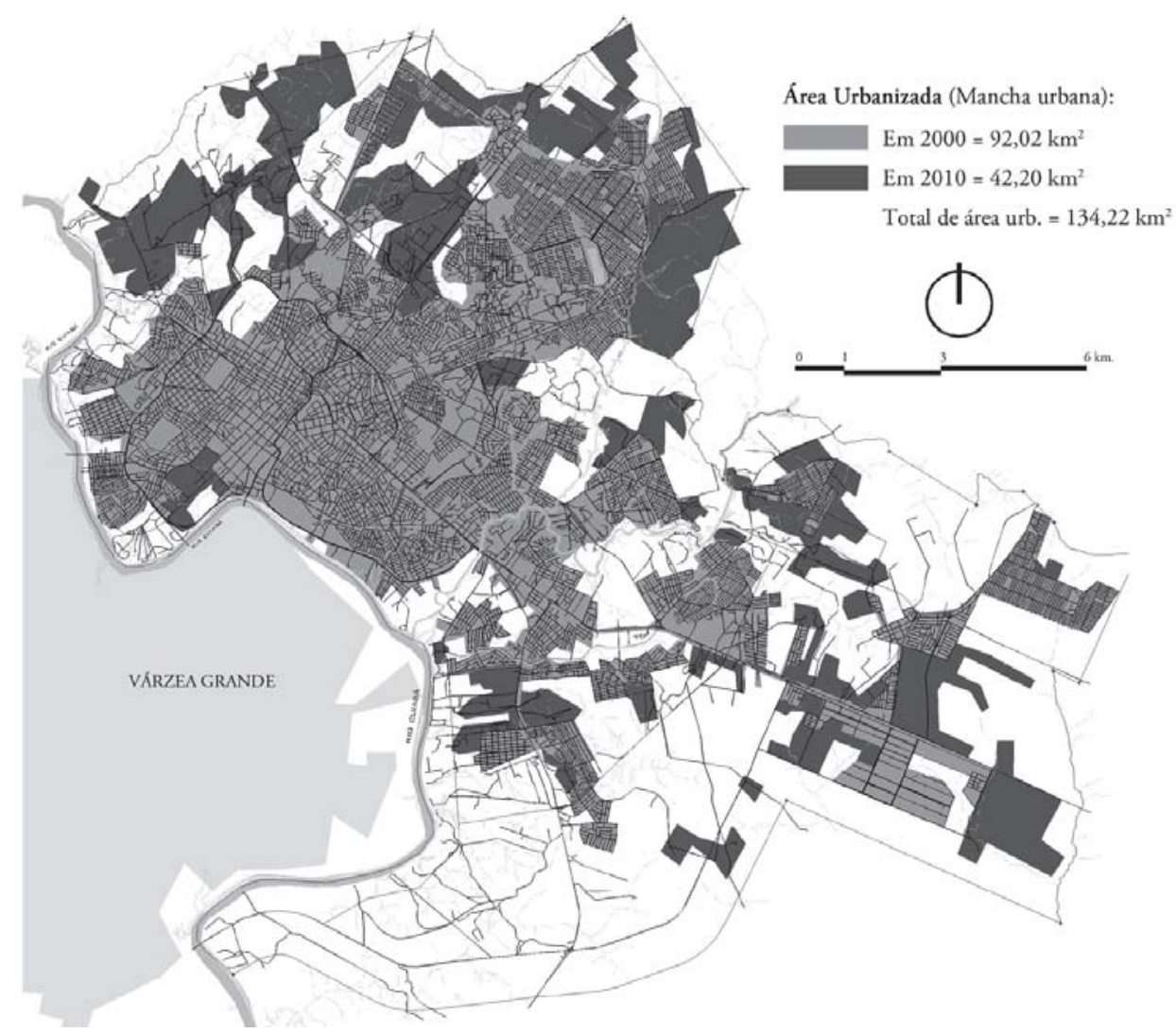

FONTE SILVA (2OI I, P. 272).

A forma de legislação urbana local está amparada no espalhamento da cidade e no seu círculo de dependência automotiva que orienta o planejamento; assim, não há ferramentas legais para coibir ou anular a dispersáo. A forma de se adaptar o perímetro urbano conforme a ocorrência de invasóes, ao longo do tempo, é equivocada, pois incentiva o comércio ilegal de terra rural e barata, mas que no futuro próximo se tornará terra urbana valorizada e com infraestrutura custeada pelo dinheiro público. 


\section{A análise qualitativa e quantitativa das doze parcelas urbanas de 25 ha selecionadas} para Cuiabá-MT

Com o intuito de aproximar as teorias e análises qualitativas e quantitativas já produzidas à realidade local, essencialmente à discrepância entre as ocupaçóes consolidadas em áreas mais centrais, com relação às áreas periurbanas, decidiu-se pela eleição de 12 áreas urbanas de 25 ha em bairros distintos 5 como objetos de estudo específico, e em conformidade com os procedimentos metodológicos adotados por Duarte (2000), Silva et al. (2010) e Romero et al. (2010). O critério de seleção para essas áreas foi, inicialmente, a separação das quatro regióes urbanas estabelecidas pela legislação municipal (Norte, Sul, Leste e Oeste) e, para cada uma dessas, foi definida a análise de uso, ocupação e ambiência de três parcelas de 25 ha, totalizando doze parcelas urbanas em doze bairros da capital para o ano de 2002 e 2010. A eleição das referidas áreas buscou representar realidades urbanas distintas, porém, de ênfase à ocupação habitacional. Assim, selecionou-se algumas áreas de ocupaçóes mais recentes (mais periféricas, como Nova Conquista, Pedra 90, Imperial, Novo Horizonte) e consolidadas (algumas mais centralizadas, a exemplo do Araés e Centro Norte), como também de diferentes classes de renda, distintas condicionantes morfológicas, ambientais, socioeconômicas, etc., caracterizando um mosaico da diversidade urbana da capital, capaz de traduzir as distintas realidades morfológicas e de uso e ocupação.

A partir das áreas definidas se optou por um estudo das condicionantes morfológicas e ambientais das parcelas urbanas selecionadas, tendo em vista a vasta literatura que apoia a interação entre tais elementos e a qualidade ambiental para as pessoas. Desta maneira, as parcelas de 25 ha se tornaram importantes, pois possibilitaram a aferição do modelo de ocupação urbana (área construída), bem como a mensuração de superfície arbórea, superfície de água, vazios urbanos, vias pavimentadas e vias sem pavimentaçáo. Esses dados foram coletados a partir do cálculo de áreas aferidas sobre imagens de satélite 6 em escala, sendo calculadas as respectivas áreas por meio de polígonos desenhados em AutoCad (2010). As referidas imagens foram capturadas entre 2002 (satélite Ikonos) a 2010 (satélite Worldview 2), portanto, as informaçóes adquiridas perfazem parte da última década (oito anos) ${ }^{7}$. (Fig. 9)

A diversidade urbana de Cuiabá está expressa em suas partes de cidade; desta forma se acreditou, a princípio, que as análises das parcelas urbanas expressariam as particularidades do desenho e da forma de ocupação nas distintas fraçóes da capital. De fato, tal ponderação se confirmou ao mensurar as áreas dos 12 bairros selecionados e, assim, tornou-se importante compreender os fatores endógenos e exógenos que determinaram os distintos modelos de uso e ocupaçáo do solo ao longo de 8 anos.

5 Atualmente, a Prefeitura de Cuiabá considera a existência de 116 bairros de forma oficial, porém, existem várias áreas em expansão e em fase de consolidação que, em poucos anos, certamente se tornarấo novos bairros na capital. Cabe reforçar que algumas ocupaçóes habitacionais já se situam além dos limites urbanos previstos em Lei.

6 Imagens de Satélite de 2002 e 2010 disponibilizadas pela Prefeitura de Cuiabá, utilizadas para o Cadastramento Imobiliário da capital, porém, de acesso e divulgaçáo restrita. Imagens 2002: satélite Ikonos na cor natural com $1 \mathrm{~m}$ de resolução / Imagens 2010: satélite Worldview 2 na cor natural com $50 \mathrm{~cm}$ de resolução disponibilizadas pela Prefeitura de Cuiabá e Universidade Federal de Mato Grosso.

7 Período no qual se contatou imagens de satélite em qualidade compatível com a forma de mapeamento e precisão de leitura dos dados. 
FIGURA 9 | As 12 áreas selecionadas nos respectivos bairros de Cuiabá-MT

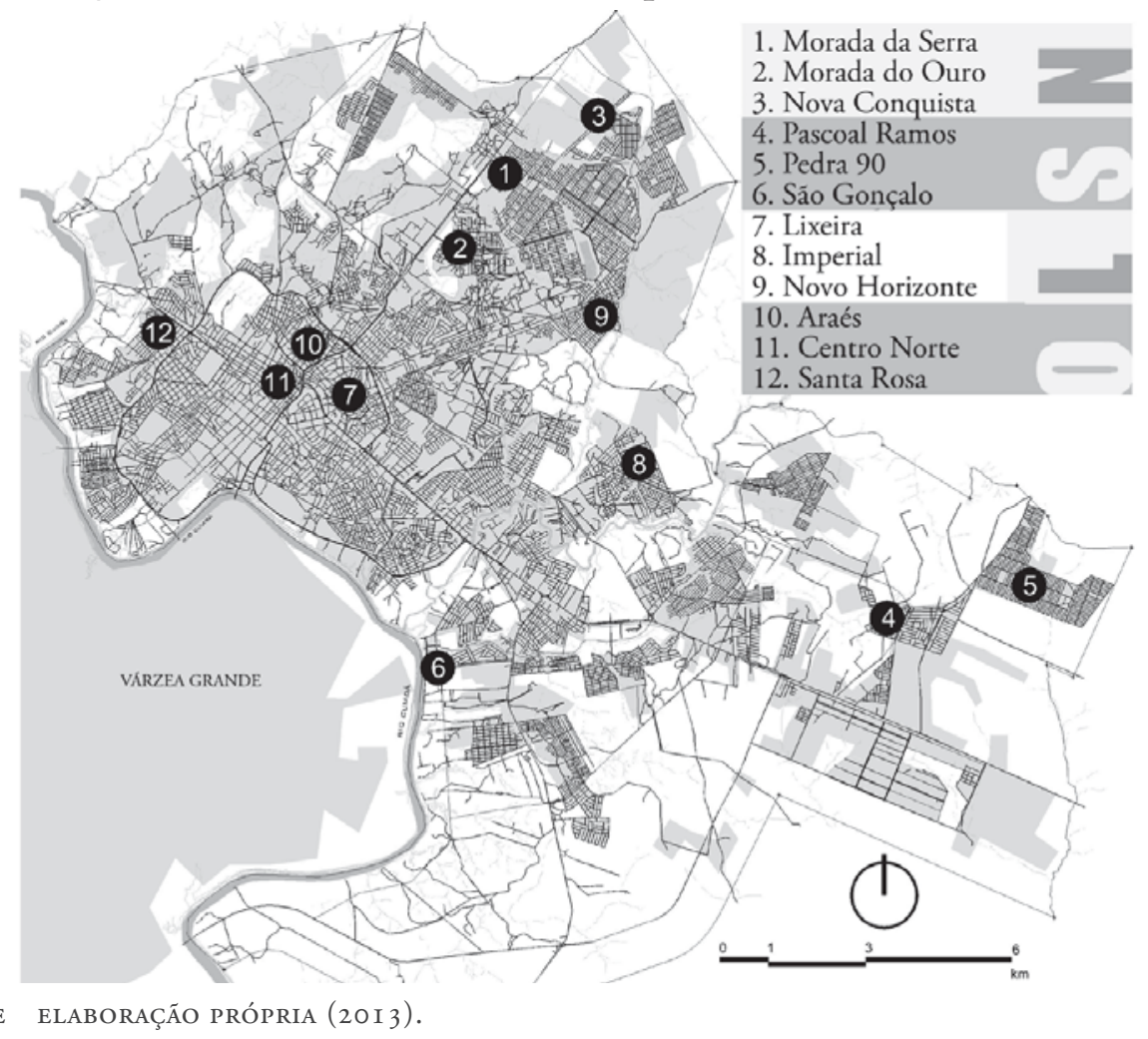

Deste modo, segue-se a definição dos objetos de análise nas 12 parcelas urbanas analisadas em 2002 e 2010 (Tabela 2):

1. Área Verde: superfície arbórea com mais de $5 \mathrm{~m}$ de diâmetro (acima de 19,6 m²), definindo-se assim o perímetro das copas das árvores de grande influência na ambiência urbana;

2. Superfície de Água: Reservas de água natural ou artificial de maior área de cobertura (acima de $100 \mathrm{~m}^{2}$ de área) e impacto climático de entorno;

3. Área Construída: Área edificada representada pelas coberturas das construçóes consolidadas. Áreas em processo de construção e, portanto, não ocupadas, foram consideradas como vazios;

4. Vias Pavimentadas: Superfície viária pavimentada (por asfalto, concreto, paralelepípedo ou pedra);

5. Vias Não-Pavimentadas: Superfície viária não pavimentada, de solo natural exposto;

6. Vazios: A quantificação de Vazios foi subdividida em dois critérios;

a. Vazios $A$ - Áreas vazias passíveis de nova ocupação (dentro do potencial construtivo dos lotes);

b. Vazios $B$ - Áreas vazias não passíveis de nova ocupação (áreas públicas, áreas de preservação ambiental permanente, acessos, passagens em áreas não destinadas ao parcelamento). 


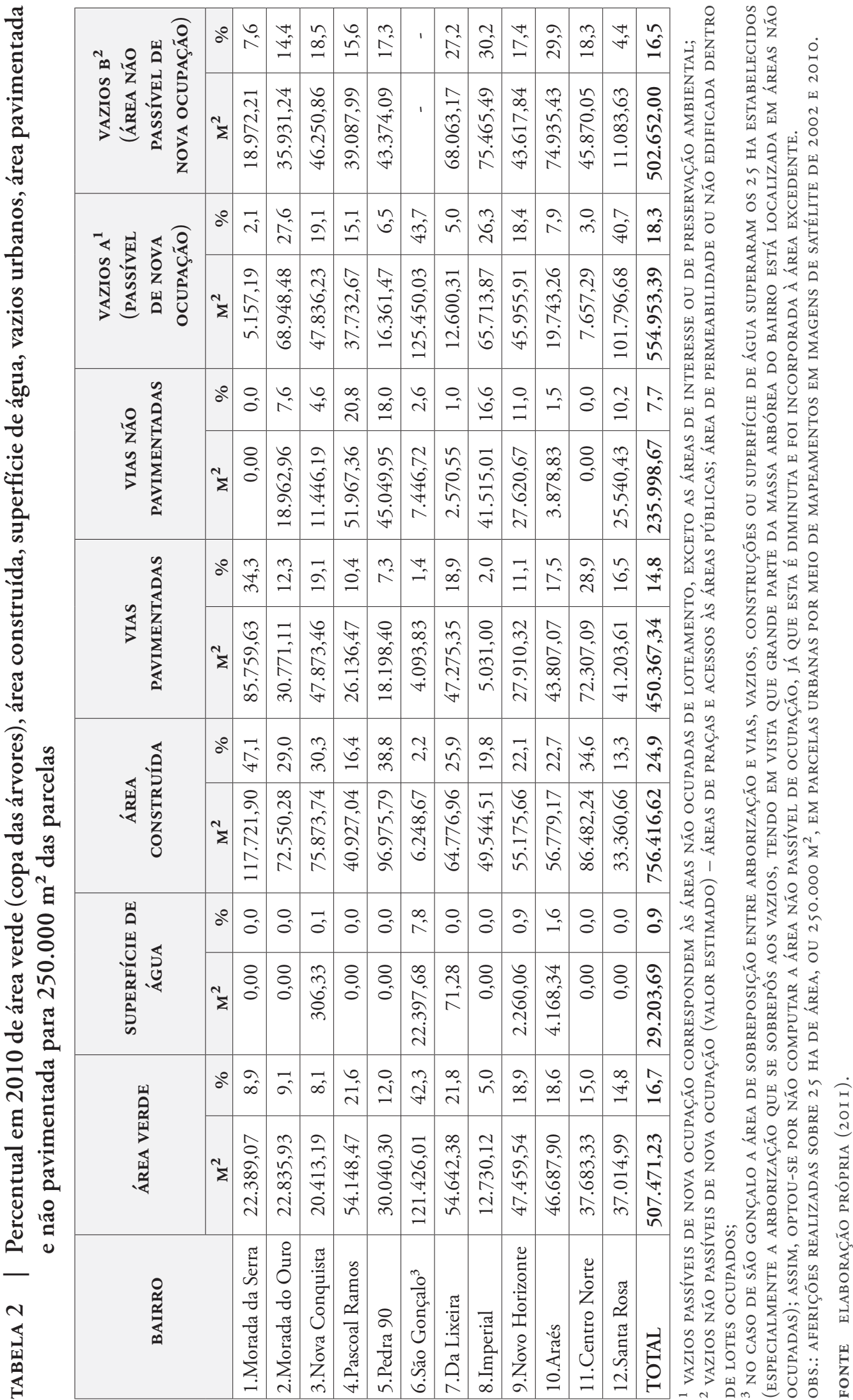


Sobre as análises realizadas no mapeamento de áreas verdes, constatou-se a diminuição em 6 áreas, sendo que os bairros Imperial (-36,46\%), Morada da Serra (-31,70\%), Pascoal Ramos (-21,49\%), Pedra 90 (-20,21\%), Araés (-13,28\%) e Centro Norte $(-3,76 \%)$, foram respectivamente os que mais diminuíram proporcionalmente suas áreas verdes. Porém, o Araés $\left(46.687,90 \mathrm{~m}^{2}\right.$, com diminuição de massa arbórea), o Novo Horizonte (47.459,54 $\mathrm{m}^{2}$, com aumento de 9,33\%), o Pascoal Ramos $\left(54.148,47 \mathrm{~m}^{2}\right.$, com perda de massa arbórea no período), da Lixeira $\left(54.425,74 \mathrm{~m}^{2}\right.$, com aumento de 4,54\%) e São Gonçalo $\left(121.426,01 \mathrm{~m}^{2}\right.$, com aumento de $18,61 \%$ ) ainda são os cinco bairros com maior superfície arbórea entre as áreas analisadas. Entretanto, as perdas de área arborizadas, no cômputo final, é um indicador preocupante para a qualidade de vida e ambiência urbana local, devendo ser esta uma inquietação à gestáo urbana pois, caso esse quadro permaneça ou se agrave, as condiçóes desfavoráveis do clima urbano de Cuiabá poderão se acentuar ao longo dos anos.

A superfície de água não estava presente na maioria das parcelas, exceto nos bairros de Nova Conquista $\left(306,33 \mathrm{~m}^{2}, 0,12 \%\right.$ do total de 25 ha, localizados apenas em 2010), Novo Horizonte (com 0,9\% do total de 25 ha), no Araés (com 1,67\%) e em São Gonçalo (com 7,8\% do total de 25 ha). Contudo, há análises distintas para os quatro casos. Com relação ao bairro de Nova Conquista, o córrego se apresentou intermitente nos dois períodos de análise, sendo identificada a sua superfície apenas no segundo mapeamento de 2010.

O Araés, por sua vez, possui córregos abertos, porém retificados e canalizados por estruturas de contenção em concreto realizadas no final da década de 1970, o que determina um desenho linear e artificial do córrego, este com alto grau de degradação e poluição (Fig. 10). A situação de São Gonçalo exemplifica uma diminuição da superfície de água em 8,45\%, que pode ser interpretada devido ao assoreamento paulatino do rio Cuiabá e à diminuição do fluxo da bacia hidrográfica - decorrente dos processos de urbanização, desflorestamento de áreas rurais e exploraçáo agropecuária intensificada nos últimos anos; todavia, essa afirmação deve ser mensurada e confirmada por pesquisas posteriores ${ }^{8}$.

A relação entre a área construída edificada (projeção das construçôes) e os vazios urbanos (áreas desocupadas que potencialmente poderiam ser utilizadas como equipamento urbano ou área loteada), apresentou dados importantes quanto ao processo de espalhamento urbano em Cuiabá. Os bairros com taxas de ocupação mais elevadas dentro dos 25 ha mapeados foram o Morada da Serra $(47,9 \%)$, o Pedra $90(38,8 \%)$ e o Centro Norte $(34,1 \%)$. Também foram estes três bairros os de menores percentuais de vazios urbanos $(2,1 \% ; 6,5 \%$ e 3,1\%, respectivamente). O bairro da Lixeira (5,04\%) e o Araés (7,9\%) também estão entre os cinco bairros com menos área disponível para ocupação.

Cabe ainda ressaltar que as imagens coletadas em 2002 são do mês de maio, e as de 2010 do mês de agosto, podendo haver oscilação dos períodos de chuva que alterariam as mediçóes de superfície de água. Assim sendo, tal análise por mapeamento de imagem de satélite deve ser realizada ao longo dos anos para se verificar as alteraçốes ambientais decorrentes das açôes antrópicas. 
FIGURA 10| Mapeamento de superfície arbórea e de água em 2002 e 2010 no bairro Araés

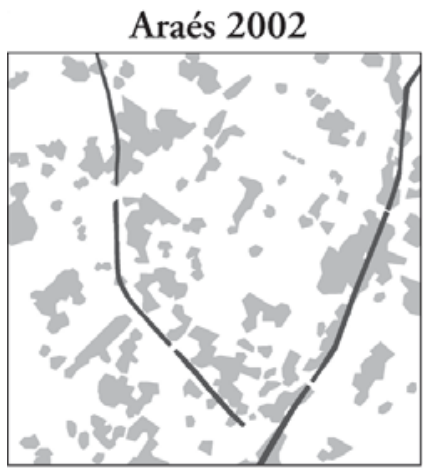

Legenda

Superfície arbórea

Superfície de água

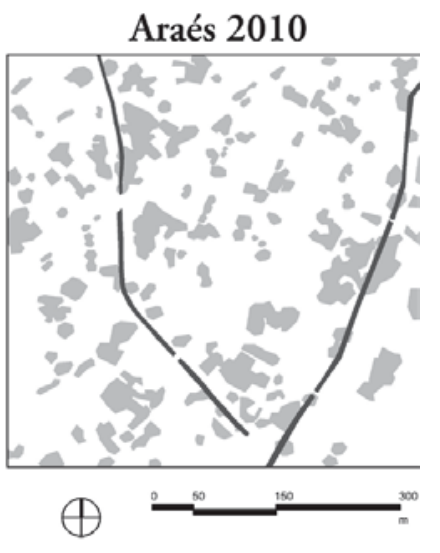

FONTE ELABORAÇÃo PRÓPRIA (2OI2).

Os bairros com maior percentual de áreas vazias passíveis de ocupação entre os 25 ha mapeados em cada caso foram: São Gonçalo Beira Rio (43,7\%), Santa Rosa (40,72\%), Imperial (26,28\%) e Morada do Ouro (27,58\%). Como já fora apresentado, o bairro São Gonçalo é de características atípicas, porém, o Santa Rosa (Fig. 11) é uma área valorizada, caracterizada como de alta renda (a maior entre os bairros de Cuiabá no ano 2000), com 37,51 salários mínimos mensais em média por domicílio (IBGE, 2010), com as maiores taxas de escolaridade e alfabetização, como também repleta de vazios e áreas de estoque imobiliário. Quanto aos vazios não passíveis de ocupação, os bairros com maior área identificada são o Imperial (30,19\%), o Araés $(25,97 \%)$ e o da Lixeira $(27,22 \%)$.

FIGURA 11| Mapeamento de área construída e vazios urbanos em 2002 e 2010 no bairro Santa Rosa, com maior taxa de educação e renda por domicílio entre os 12 bairros analisados, porém, com alto percentual de vazios e área não pavimentada.

Santa Rosa 2002

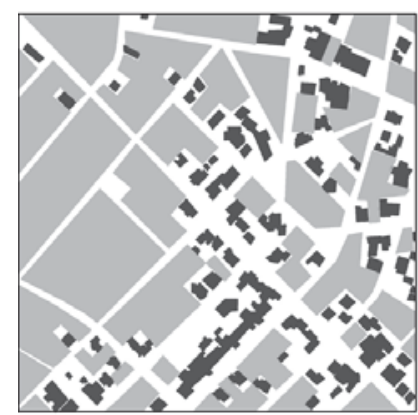

Legenda

Projeção de área construída

Vazios urbanos
Santa Rosa 2010

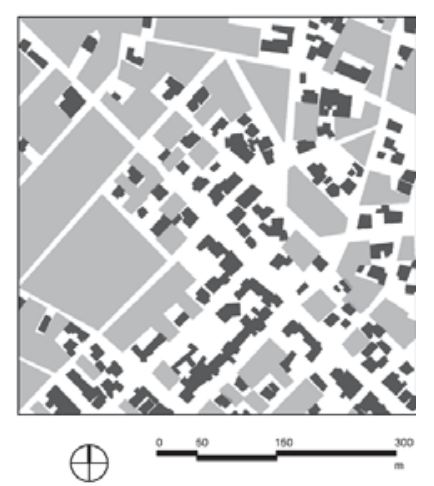

FONTE ELABORAÇÃo PRÓPRIA (2OI2). 
Contudo, o Santa Rosa não possui todas as vias pavimentadas, apesar da forte especulação e alta renda domiciliar, pois cerca de 10,22\% da área total está sem pavimentação, enquanto $16,48 \%$ de vias nos 25 ha são pavimentadas. Bairros como Morada da Serra (34,30\%), Centro Norte (28,92\%), ambos totalmente pavimentados, e Nova Conquista (19,15\%), Da Lixeira (18,91), e Araés (17,52\%), foram os que apresentaram melhores percentuais que o Santa Rosa. Dentre esses, apenas Morada da Serra e Nova Conquista estão em áreas mais periféricas. No entanto, os bairros com piores índices de pavimentação foram, respectivamente, o Pascoal Ramos (com 20,79\% de vias não pavimentadas) -, Pedra 90 (com 18,02\%), Imperial (com 16,61\%) e Novo Horizonte (com 11,05\%), todos em áreas mais afastadas do centro e de baixa renda per capita.

Em síntese, compreendeu-se a impossibilidade de se identificar padróes de urbanização ou reproduçóes de modelos de planejamento, seja de cunho ideológico ou político, tendo em vista que a cidade de Cuiabá parece estar pouco inserida num processo de desenvolvimento urbano, planejado e orquestrado por meios técnicos, pela gestáo pública local. Em geral, os bairros periféricos estão mais suscetíveis aos processos de intensificação das ocupaçóes iniciadas nas últimas décadas, por isso coincide, por exemplo, com o aumento de construçóes, vias e de arborização nesse período; contudo, percebe-se em algumas áreas um grande processo de desflorestamentos de áreas naturais e de vegetação exuberante nas áreas periurbanas, deflagrando um processo de invasão do urbano sobre o sistema-entorno que poderia ser evitado, tendo em vista a observaçáo de extensas áreas vazias em bairros já ocupados e com infraestrutura. $\mathrm{O}$ verde também se reduziu nos bairros mais antigos e consolidados, o que demonstra um certo descaso comunitário e da gestão em relação à arborização. Torna-se ainda importante correlacionar o processo de ocupação dos bairros de Cuiabá às condicionantes socioeconômicas e educacionais, demonstrando que há o aumento de renda em áreas com maior escolaridade entre os moradores, como também conforme haja maior proximidade com as áreas mais centralizadas, caracterizando-se um processo de segregação socioespacial identificado.

\section{Diretrizes de urbanismo sustentável para o século XXI em Cuiabá-MT: análise qualitativa}

Para os próximos anos e com a implementaçáo dos programas federais de aceleração do crescimento (os PACs), a cidade e sua região será mais uma vez o palco de vultosos investimentos para atender a economia crescente, como também para sediar a Copa do Mundo de Futebol em 2014․ Deste modo, Cuiabá, assim como as demais cidades-sedes brasileiras, será palco de um evento bilionário e mundialmente acompanhado, que vai refletir na economia local e nacional, principalmente quanto aos serviços, ao turismo e à exportaçáo de produtos regionais.

No dia 20 de outubro de 2011 foi divulgada pela FIFA em Zurique, Suíça, a lista das cidadessedes da Copa do Mundo de Futebol em 2014, e da Copa das Confederaçóes em 2013, nesta última Cuiabá estava excluída entre as cidades eleitas: Belo Horizonte, Fortaleza, Brasília e Rio de Janeiro, ficando as cidades de Recife e Salvador de sobreaviso. Para a Copa do Mundo, Cuiabá sediará quatro jogos da primeira fase. 
Contudo, se a princípio acreditava-se que as obras urbanas de infraestrutura e equipamentos para o megaevento da FIFA em Cuiabá - dotados de grandes orçamentos federais, estaduais e, numa menor parcela, municipais -, poderiam suprir as demandas urbanas ultrapassadas por projetos e obras estruturantes não realizados ao longo de décadas, atualmente o cenário que se tem é outro. A ausência de informaçôes sobre os projetos à sociedade, o náo cumprimento dos prazos das obras, a elevação do custo das obras sem previsão para conclusão da maioria das intervençóes, os equívocos técnicos de projeto e execução nas obras de engenharia e infraestrutura, as isençóes fiscais, a queda na arrecadação tributária e a falta de transparência nos processos de contratação e prestação de serviços públicos, são alguns dos principais problemas diagnosticados.

A sociedade, por sua vez, tem sido afetada de diversas formas, num impacto direto do canteiro de obras na cidade (que mudou toda a rotina urbana, prejudicando o tráfego, aumentando-se custos e tempo de deslocamento, o aumento da poluição por partículas de suspensão, repercussão negativa sobre o comércio e a economia urbana, as demoliçôes e desapropriaçóes sem projetos executivos definidos, destruição da paisagem e remoção de corredores verdes, etc.). (Fig. 12)

FIGURA 12| Imagens de obras para a Copa de 2014 que apresentaram problemas de execuçáo em Cuiabá-MT
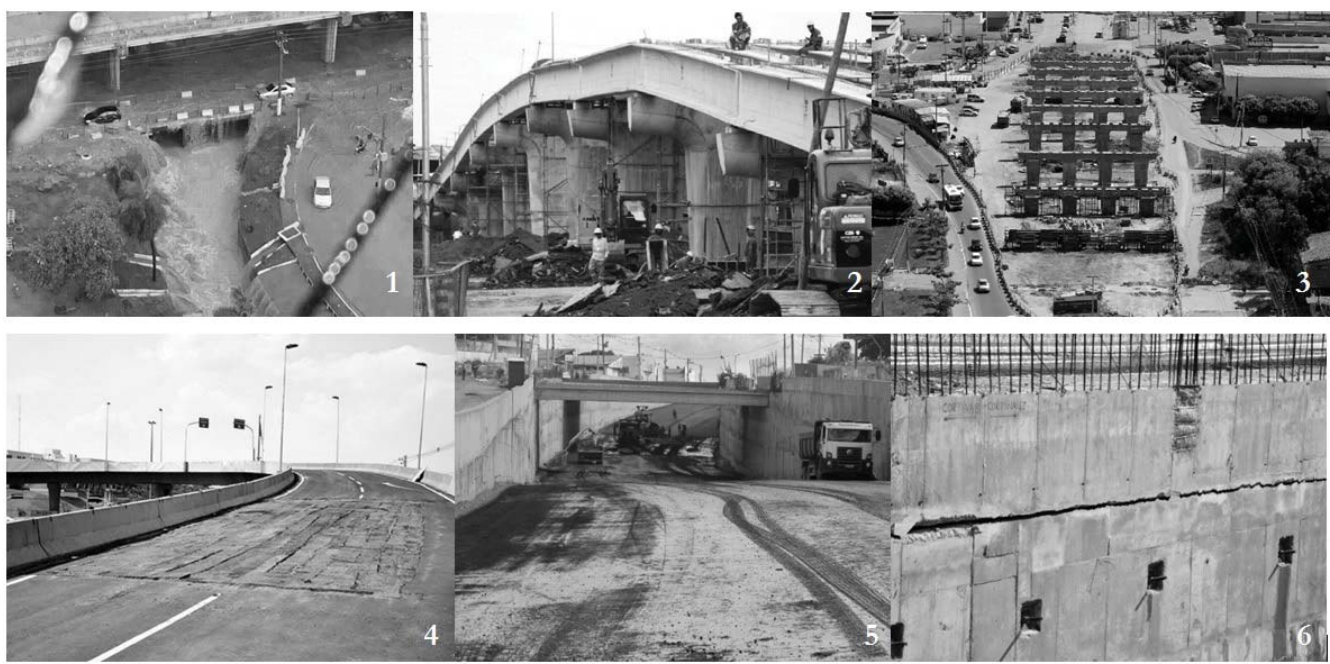

LEGENDA/ESQUERDA À DIREITA: FIG.(S) I E 2 - VIADUTO DA UFMT COM PROBLEMAS ESTRUTURAIS E DE DRENAGEM (FONTE: <WWW.NOTICIASTODAHORA.COM.BR>/<WWW.PROSAEPOLITICA.COM.BR>); FIG. 3 - VIADUTO RODOFERROVIÁRIO (FONTE: WWW.COPA2OI 4.GOV.BR); FIG. 4 - VIADUTO DA SEFAZ COM PROBLEMAS DE PAVIMENTAÇÃO (FONTE: WWW.ISSOENOTICIA.COM.BR); FIG.(s) 5 E 6 - VIADUTO SANTA ROSA COM PROBLEMAS DE DRENAGEM E EXECUÇÃO (FONTE: WWW.GI.GLOBO.COM).

FONTE ADAPTADO PELOS AUTORES (20I4).

Se em 2007, a CBF (Confederaçáo Brasileira de Futebol) estimava gastar por volta de $\mathrm{R} \$ 2,2$ bilhóes nas obras para a realização do evento no Brasil, com investimentos privados em sua maioria, hoje já se fala em cifras acima de $\mathrm{R} \$ 30$ bilhóes, com mais de $90 \%$ de recursos e financiamentos públicos. E Cuiabá também sofreu com os acréscimos sucessivos nos custos para viabilizar os investimentos, pois no início 
o governo planejava gastar R $\$ 950$ milhóes, mas, atualmente, já se ultrapassou a casa dos $\mathrm{R} \$ 2$ bilhóes, sem nenhum investimento privado, e com mais de $50 \%$ de recursos provenientes do estado e município.

Os impactos ambientais já se prenunciam com a ênfase ao sistema viário (Fig. 13) em detrimento do pedestre e ciclistas, sendo esta uma das diretrizes equivocadas de planejamento. Assim, alargam-se avenidas, constroem-se viadutos, retiram-se milhares de árvores da paisagem urbana dos canteiros centrais que agora cedem espaço aos novos modais tecnológicos (Veículo Leve sobre Trilho VLT), todavia, sem um plano urbano prévio, capaz de orientar o desenvolvimento da cidade em médio e longo prazo, mensurando e mitigando seus impactos e prevendo potencialidades. Numa sociedade pouco informada sobre a política urbana e as ações de governo, de participação reduzida nos processos decisórios da cidade (apesar de democraticamente instituída), e com problemas institucionais e legais que sobrepóem às diversas escalas sociais, constitui-se num terreno fértil às incorporadoras e agentes econômicos da especulação, que detém acesso à mídia, aos setores políticos e que visam, acima de tudo, o lucro de suas atividades.

FIgURA 13| O Ciclo de Dependência Automotiva nos sistemas urbanos, caracteriza que a dinâmica urbana está focada na circulação, armazenamento e aquisição de automóveis, e estes induzem o planejamento e uso do solo em virtude de suas características de transporte

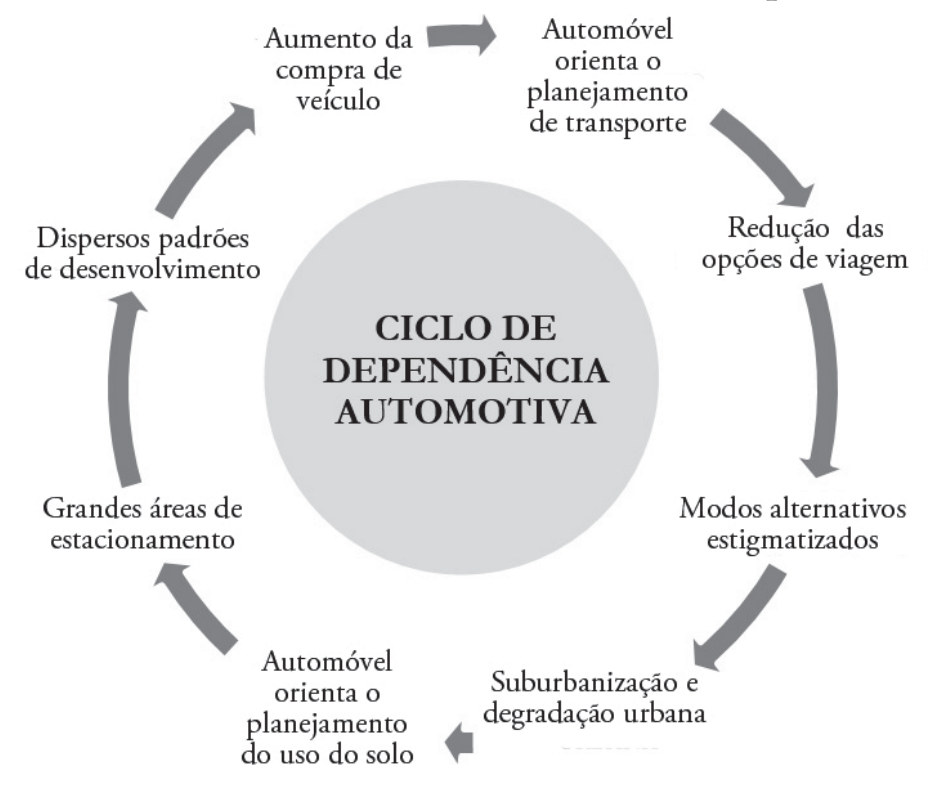

FONTE ADAPTADO DE LITMAN (2002) E COLBy (2006).

Confirmando esses prognósticos, segundo Leite (2014), dos $23 \mathrm{~km}$ projetados do sistema VLT, serão concluídos apenas $5,7 \mathrm{~km}$ entre o aeroporto Marechal Rondon e a estação nas proximidades do Rio Cuiabá, que se conectará à Arena Pantanal por transporte coletivo veicular. Cabe reforçar que o vLT é o projeto estruturante mais importante e oneroso para a cidade, e custará $\mathrm{R} \$ 1,447$ bilháo ao todo. 
O projeto da Arena Pantanal, apesar de um incêndio ocorrido em outubro de 2013, é a obra que está mais adiantada e deverá ser inaugurada entre março ou abril de 2014 , com três a quatro meses de atraso. O projeto custará $\mathrm{R} \$ 525$ milhóes, e foi orçado inicialmente em $\mathrm{R} \$ 454$ milhóes, recebendo um aditivo de 15,6\% sobre o custo inicial estimado. (Fig. 14)

Figura 14| Imagens da Arena Pantanal, à esquerda uma imagem do incêndio ocorrido em outubro de 2013, e à direita, uma vista atual da construção em fase final

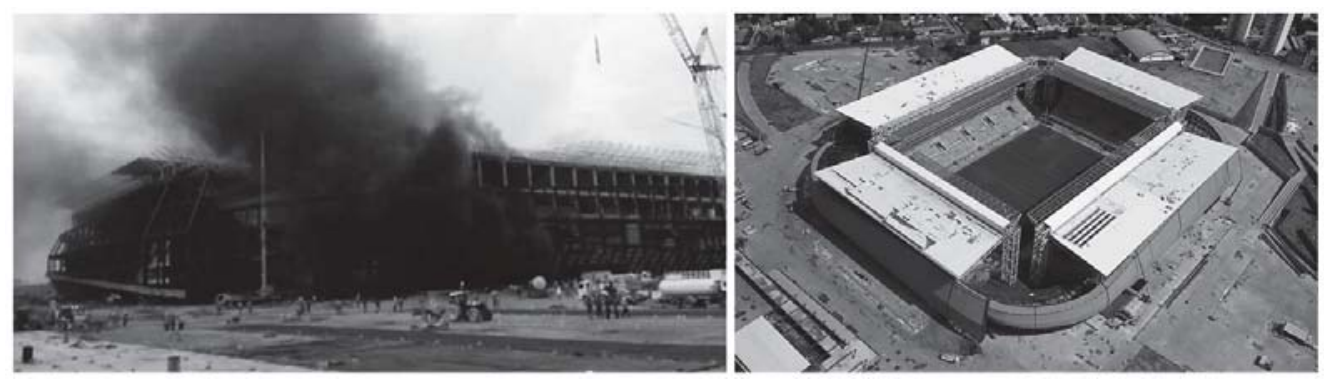

FONTE ADAPTADO (2OI4) DE <WWW.SUPERESPORTES.COM.BR> (2OI3) E <WWW.F.I.UOL.COM.BR> (2OI4).

Quanto à mobilidade urbana, os problemas em Cuiabá tendem a se acentuar. $\mathrm{Na}$ última década, o número de veículos em Mato Grosso praticamente triplicou, saltando de 380 mil para 1,1 milhão. Deste total, há em todo Estado 534,5 mil automóveis, 490 mil motos e 9 mil ônibus. A cidade de Cuiabá detém 262,9 mil veículos, sendo 175 mil automóveis, 65 mil motos e 2,4 mil ônibus. Se dividir o número total de veículos pela população da capital chega-se a uma proporção aproximada de 0,48 veículos por habitante, enquanto a média nacional é de 0,34 veículo por habitante e a mundial é de aproximadamente 0,17 (Departamento Nacional de Trânsito [Denatran], 2011). Considerando que o espaço médio necessário para uma vaga de estacionamento e acessos é de 20 metros quadrados, em Cuiabá é necessário haver 3,5 milhóes de metros quadrados para essa finalidade.

Estudos recentes ${ }^{10}$ de mobilidade confrontam os dados alarmantes sobre o aumento da frota de veículos automotivos em 100\% de automóveis e 440\% de motocicletas na última década, totalizando mais de 350 mil veículos na região de Cuiabá e Várzea Grande. Ainda conforme o estudo, com data de 2005, foi informado que em Cuiabá são realizadas 796 mil viagens diárias e, destas, 339 mil em transporte coletivo, 169,5 mil em automóveis individuais e 261,7 mil por meios não motorizados. Ou seja, do total de viagens diárias, cerca de $33 \%$ são realizadas principalmente de bicicleta, o que condiciona a uma falta de percepção e ação pública sobre o problema, quando se depara que a cidade é praticamente desprovida de ciclovias para essa mobilidade alternativa. Por outro lado, o fácil acesso às linhas de crédito, incentivos fiscais às vendas de veículos, aumento dos postos de emprego e de renda da classe média, acompanhados por uma estabilidade econômica, acabam por difundir a cultura do

10 Parte do conteúdo da audiência pública pode ser consultada no site http://www.copanopantanal. com.br/?p=fotosmobilidade 
automóvel pelas cidades brasileiras, deixando em segundo plano os investimentos em transporte público e alternativo. $\mathrm{O}$ planejamento e a arquitetura fecham esse ciclo, condicionando baixas densidades ocupacionais, isolamento de funçóes urbanas e de usos segregados às facilidades de estacionamento e disponibilidade viária, que incentivam o aumento exponencial de carros e motocicletas a sobrecarregar o fluxo do sistema viário.

No âmbito urbano geral, as conjecturas da economia, da demografia, da habitação, da mobilidade, do social e, enfim, do ambiental, requerem algumas ações gerais para minimizar a dispersão da cidade, que atinge todas as esferas de gestão das cidades (federal, estadual e municipal). Uma abordagem de cenários futuros é importante para que se pontue de forma qualitativa o urbano de Cuiabá que se vislumbra, dependente de açóes públicas, privadas e coletivas no campo da sustentabilidade urbana para os anos que se seguirão.

Se as políticas públicas direcionarem para o não entendimento das possíveis consequências da dispersão urbana, como o que ocorre atualmente, o cenário da cidade de Cuiabá na próxima década poderá ser muito pessimista. Os caminhos para uma cidade sustentável são extremamente difíceis, pois requerem o entendimento e a ação social em sinergia com as açóes públicas, característica esta muito longe do atual quadro político e social da cidade. $\mathrm{O}$ grande desafio está na mudança desse paradigma e, muitas vezes (como se sabe na história humana), só se altera uma estrutura viciada por meio de sua ruptura ou crise acentuada.

Caso se decida por aumentar a densidade de Cuiabá sem expandir o atual perímetro urbano, é possível duplicar ou até triplicar a população da cidade com qualidade ambiental - desde que se mantenha a proporçáo adequada de áreas verdes, superfície de água, equipamentos e infraestrutura urbana em relaçáo à massa edificada mais compacta -, atendendo a todas as projeçóes populacionais para a capital que apontam para o ápice de um milhão de habitantes, talvez, para os próximos 15 anos. Contudo, o perímetro urbano atual, já definido por lei municipal, certamente pode comportar mais de 1,6 milhóes de pessoas investindo-se em adensamento residencial, reocupação de áreas centrais e vazios urbanos, fortalecendo sub-centros de serviços, pequenas indústrias e emprego, possibilitando a mobilidade urbana alternativa e aplicando novas tecnologias ambientais sustentáveis para a reduçáo de resíduos e consumo de energia. No entanto, a sustentabilidade urbana depende de conscientização coletiva e, talvez um dos fatores mais importantes, da vontade política para se planejar dentro desses parâmetros.

Em conformidade com os estudos realizados, percebeu-se que os efeitos do espalhamento urbano atuam sobre diversos âmbitos, o que neste trabalho foi classificado como o quadripé da sustentabilidade: o social, o econômico, o ambiental e o político (que abrange ainda a gestáo urbana e a governança), que são aspectos perceptivos em relação às interaçóes humanas e seus efeitos no espaço; este, aqui, é classificado como o urbano, constituindo-se no último âmbito qualitativo analisado. (Fig. 15) 
FIGURA 15| Diagrama representativo do efeito do espalhamento urbano sobre as esferas de análise social, econômica, ambiental, política e urbana

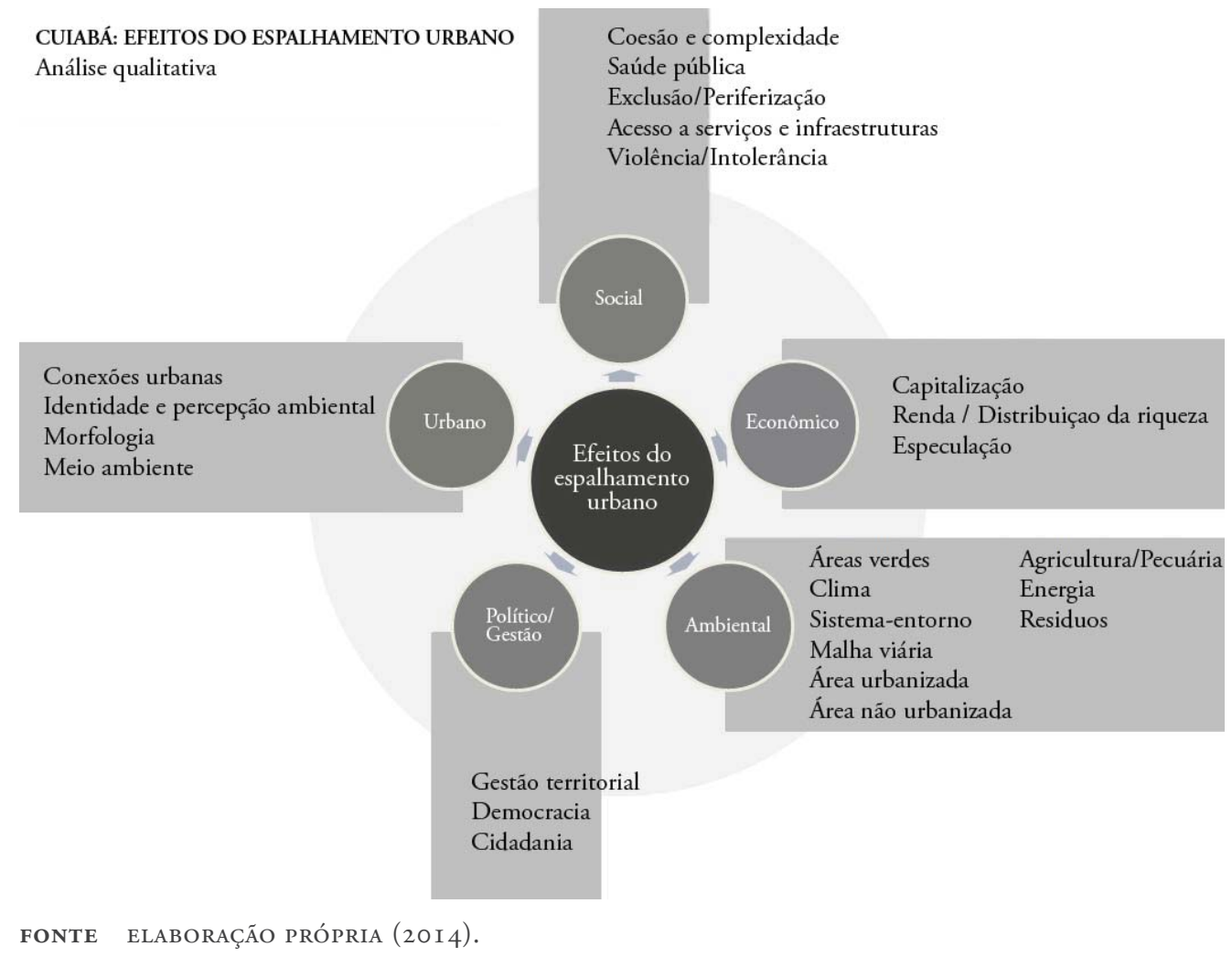

\section{Consideraçóes finais}

A premissa desta pesquisa se situa em apresentar à sociedade as discussóes acerca da sustentabilidade urbana e suas aplicaçóes teóricas no futuro das cidades brasileiras, sendo seus métodos e diretrizes de planejamento reproduzíveis a outras realidades urbanas desse contexto. Assim, as pesquisas realizadas buscam esse diálogo com a coletividade, demonstrando o que ocorre com as cidades no mundo e no Brasil, apontando seus problemas e, conseguintemente, vislumbrando possíveis soluçôes a essa complexa discussão com a aplicação metodológica para a cidade de Cuiabá. Por sua vez, a referida aplicaçáo de análises urbanas para este sítio urbano demonstrou a necessidade do planejamento local se instrumentalizar, tornando-se mais técnico e capaz de acompanhar a dinâmica urbana, pois, a exemplo de muitas cidades brasileiras, a região não tem conseguido planejar, controlar e ordenar o território urbano e regional de forma abrangente e integrada. Procedeu-se, ainda, à compreensáo dos cenários e das respectivas condicionantes e configuraçóes urbanas em escala mundial e, a partir de então, determinou-se os caminhos alternativos para um urbanismo sustentável factível em âmbito nacional, coerente ao contexto latino-americano, considerando-se as particularidades complexas e inerentes a esse processo investigativo. A partir de um repertório teórico e de análises correlatas de cidades, teorias, conceitos, formas de planejamento e gestão urbana, compreendeu-se que alguns 
preceitos urbanísticos recorrentes podem ser aplicados às cidades brasileiras, com o intuito de torná-las menos impactantes ao meio e ao sistema-entorno, promovendo-se ainda a qualidade de vida, melhor ambiência e a coesáo social, entre outras benesses urbanísticas possíveis.

Após a definição da hipótese sobre a recorrência de um fenômeno de dispersão urbana atuante em Cuiabá, com ênfase à última década, definiu-se a rotina de pesquisa, os objetivos e os procedimentos metodológicos. Estes se demonstraram adequados quando passam a integrar a abordagem sistêmica da análise urbana à percepção da cidade em escalas (macro, meso e micro). Desta forma, pôde-se analisar a forma de ocupação genérica (a da mancha urbana) e das particularidades (referentes à escala do sítio / bairro). Assim, as determinantes atuantes sobre a cidade puderam ser identificadas desde o contexto regional-territorial, do urbano, da cidade (mancha da dispersão urbana) e das parcelas dos bairros (em 25 ha nos 12 bairros escolhidos) selecionados conforme amostragem por região. Parcelas urbanas que buscaram traduzir, a partir de seus fragmentos, o mosaico urbano de Cuiabá como um todo sistêmico, todavia, reforçaram a necessidade de se dar prosseguimento de pesquisa à essas análises em tempos posteriores, como também em mais porçóes e bairros da cidade.

As frentes de análise urbana, como já foi dito, sempre buscaram interpretar os aspectos sociais, econômicos, ambientais e de gestão/política, porém sem negligenciar os aspectos socioculturais e históricos. O reconhecimento da cultura, da memória e da história urbana, sáo elementos enriquecedores à cidade contemporânea, pois a sustentabilidade da cidade deve priorizar as manifestaçóes culturais regionalistas, já que estas personificam o lugar e transmitem a noção de pertencimento das pessoas ao seu lócus. A identidade urbana e a cidadania coletiva estabelecem níveis de participaçáo e civilidade imprescindíveis à qualidade da cidade para o futuro. "Sustentar" as relaçôes culturais e a história urbana é permitir a continuidade do respeito coletivo e do sentido de comunidade às geraçóes futuras. Deste modo, a literatura aponta que a compactaçáo urbana pode determinar essa aproximação comunitária e da coletividade, por meio da morfologia densa, mix de funçóes e aumento do capital-social.

A mobilidade urbana, centrada no automóvel, e a falta de controle sobre os atores especulativos imobiliários ou mesmo sobre as invasôes, tem acentuado a dispersão do perímetro urbano e aumentado as distâncias e custos para se locomover pela cidade, como também agravando os índices de poluição e degradação ambiental. Por outro lado, os projetos urbanos que se vislumbram para a Copa do Mundo de 2014 se situam sobre modelos de locomoção assentados num território disperso (e em processo de espalhamento), náo se considerando alternativas de maior densidade urbana, acessibilidade para pedestre e ciclistas, entre outras soluçóes que poderiam mudar a configuraçáo urbana de forma mais sustentável. Nesse cenário, tende-se à crescente diminuição da coesão social, fragmentaçáo socioespacial dos bairros, esvaziamento e obsolescência de áreas centrais dotadas de acessibilidade e infraestrutura, perda do sentido de domínio das pessoas, dentre outros aspectos concernentes à cidade dispersa. As intervençóes urbanas previstas apontam para um processo de gentrificação e enobrecimento de algumas áreas de interesse especulativo, em 
detrimento da periferia de menor renda, que continuará à margem dos investimentos urbanos e sem acesso direto ao VLT (que prioriza o fluxo de turistas). É compreensível que os problemas enfrentados na coordenação dos grandes projetos urbanos para a cidade, nos últimos anos, decorrem de uma desorganizaçáo legislativa e institucional em várias esferas, na qual as autarquias e diversos órgáos de governo (federal, estadual e municipal) não atuam de forma planejada e sinérgica nos processos de participação social, desenvolvimento, aprovação e fiscalização dos projetos e obras. O próprio processo licitatório no Brasil é bastante questionável, pois estabelece a competição de empresas pelo menor preço orçado de obra como um dos critérios principais de escolha.

A partir da aplicação dos estudos, como resultado da pesquisa, identificou-se que o fenômeno da dispersão urbana invadiu um território extenso na última década em Cuiabá, pois, o que era 9.202 ha em 2000, passou a 13.422 em 2010. Contudo, enquanto a área urbana avançou $45,86 \%$, a população da cidade cresceu apenas 13,54\% - de 476,5 mil habitantes para 541 mil nesse mesmo período. Deste modo, a densidade urbana reduziu-se, na última década, de 51,8 hab/ha para 40,3 hab/ha. Ou seja, conforme as recomendaçóes de ambiência urbana qualitativa apresentadas para a cidade, a população atual de 541 mil habitantes poderia atingir mais de 800 mil habitantes sem ocupar novas áreas, apenas densificando os espaços já existentes -vazios ou subutilizados -, desde que se mantivessem os percentuais adequados de área verde e superfície de água frente à necessária diversidade morfológica da área ocupada. Inserindo-se neste quadro as áreas vazias passíveis de ocupação, a cidade poderia atingir, seguramente, cerca de 1,1 milhão de habitantes sem ocupar reservas naturais ou áreas fora do perímetro urbano atualmente delimitado.

Esses apontamentos confirmam a inconsistência de um planejamento sem orientaçóes técnicas e que incentivam a dispersão e ocupação de áreas periurbanas. Assim, deve-se pesquisar e simular modelos de densificação urbana para a cidade, pois, conforme os estudos de climatologia urbana consultados, estima-se que a densidade bruta dos bairros pode atingir até $60 \mathrm{hab} / \mathrm{ha}$ (50\% acima da densidade atual) em média, com qualidade ambiental, desde que mantida uma proporção adequada de superfície arbórea entre 30\% a 35\%, superfície de água de 0,2 a 1\%, vazios em até $3 \%$, vias em até $20 \%$, projeção de área construída de até $50 \%$, com coeficiente de aproveitamento médio de 1,5 .

$\mathrm{Na}$ escala regional interurbana, ferramentas legais como o ICMS ecológico ou socioambiental podem atuar sobre investimentos e promovendo desenvolvimento nas regióes mais pobres ou que detenham maior percentual de áreas naturais preservadas, atenuando o fluxo migratório para a capital e melhorando a qualidade de vida regional. $\mathrm{Na}$ escala urbana, o IPTU verde, ecológico ou socioambiental pode premiar os lotes com maiores incentivos à maior permeabilidade do solo, maior densidade habitacional, tratamento de resíduos, coleta e aproveitamento de água pluvial, captaçáo de energia solar. Por sua vez, o estado e a Uniáo podem repassar maiores recursos aos municípios que praticam a gestáo sustentável, distribuindo compensaçóes fiscais de forma igualitária, sem prejudicar a arrecadação da cidade, ou do estado como um todo. 
Os aspectos socioeconômicos e ambientais são também afetados na discussão sobre a sustentabilidade urbana. A proposição de uma maior compactação das partes, intensificação de subcentros, aproximando-se distâncias e deslocamentos diários entre a casa, o trabalho e o lazer, transforma a dinâmica urbana e a qualidade de vida para todos. Além de baratear o acesso à infraestrutura, habitação e transporte, a compactação urbana associada a uma morfologia policêntrica permite que mais pessoas tenham acesso à cidade a um custo per capita mais baixo para a gestáo, além de otimizar o consumo de recursos naturais, energia e território verde no sistema-entorno. Porém, é necessário estabelecer parâmetros de análise da compactação urbana e sua eficácia, controlando impactos climáticos, otimizando o acesso à infraestrutura, serviços e equipamentos e, mantendose assim, a sustentabilidade urbana ao longo do tempo. Mais uma vez, é reforçado o acompanhamento técnico dos processos urbanos pelo planejamento integrado.

A cidade sustentável também coexiste à economia urbana, pois numa cidade em que se adotem tais critérios de ocupação, controle e gestão, certamente a economia urbana é intensificada, a exemplo do que se verificou em outras cidades no Brasil e no mundo. A geração de "empregos verdes", derivados de novas tecnologias ambientais e da gestão ecológica da cidade, tende a atuar num ciclo virtuoso para a sustentabilidade urbana. Para tanto, é necessário investir em polos de ciência, tecnologia e inovaçáo nessa área, o que pode reverberar em maiores oportunidades de negócios, empregos e marketing urbano para as cidades.

Deve-se pensar a cidade contemporânea sob formas compactas de ocupaçáo, aumentando-se a sua complexidade e eficiência, promovendo-se assim a estabilidade social, econômica e ambiental. Para tanto, é necessária a aplicação e mensuraçáo de indicadores urbanos adaptados para as análises complexas do urbano em sua regiáo específica, conforme suas condicionantes regionais, para que a gestão da cidade tenha, em mãos, ferramentas eficazes no acompanhamento das mutaçóes urbanas ao longo do tempo.

Por fim, concluiu-se a partir dos estudos sobre a dispersão urbana em Cuiabá e de seus consequentes impactos socioespaciais, socioeconômicos, ambientais, culturais e de planejamento urbano e regional, que a gestâo urbana da capital deve acompanhar tecnicamente o processo de dispersão urbana identificado, recorrendo-se às propostas de aplicaçáo e recomendaçóes apresentadas de planejamento urbano e regional, integrado e sustentável.

A cidade sustentável do futuro deverá agregar novos valores à urbanidade e ao seu planejamento, integrando regióes, minimizando impactos, potencializando investimentos em prol do coletivo e da melhoria da qualidade de vida para seus cidadáos. A coesão social deve ser incentivada pela maior densidade urbana e valorização dos espaços públicos, minimizando-se assim a segregaçáo socioespacial. A cidade deve ser planejada como um metabolismo circular, reciclando, reaproveitando, otimizando energia, reduzindo o consumo em várias escalas, minimizando resíduos, poluiçóes e território ocupado. As legislaçóes devem acompanhar as mudanças, contudo, a aplicação e fiscalizaçáo das leis devem ser rigorosas para que o planejamento urbano e regional atue como diretriz reguladora eficaz. Enfim, a sustentabilidade urbana perpassa por essa forma de ordenação eficiente e técnica, aplicando-se novas tecnologias, minimizando desigualdades e voltada para as pessoas, não apenas para as máquinas. 


\section{Referências bibliográficas}

Arbury, J. (2005). From Urban Sprawl to Compact City: An Analysis of Urban Growth Management in Auckland. Master's Thesis. Auckland, New Zealand, University of Auckland. Disponível em http://portal.jarbury.net/thesis.pdf

Bertaud, A. (2004). The spatial organization of cities: Deliberate outcome or unforeseen consequence? In Alain Bertaud Web Page. Disponível em http://alain-bertaud.com/images/AB_ The_spatial_organization_of_cities_Version_3.pdf

Brasil. (2012). Tribunal de Contas da União. O TCU e a Copa do Mundo de 2014: relatório de situação - março de 2012 / Tribunal de Contas da União. Brasília: Tcu.

Confederação Nacional dos Municípios (CNM). Brasília: CNM, 2010. Disponível em http:// cnm.org.br

Colby, G. (2006) Urban Sprawl, Auto Dependency And Poverty. Amherst, MA: University of Massachusetts Amherst/Commonwealth College. Disponível em http://www.comcol. umass.edu/dbc/pdfs/Greg_Colby_Publication_Version.pdf

Centro de Previsão de Tempo e Estudos Climáticos / Instituto Nacional de Pesquisas Espaciais (CPTEC/INPE). (2010). Disponível em http://www.cptec.inpe.br/cidades/tempo/226

Cuiabá, Prefeitura Municipal de. (2010). Perfil Socioeconômico de Cuiabá. - Cuiabá: IPDU/ Ed. Central de Texto.

Departamento Nacional de Trânsito (Denatran) - Frota de Veículos. (2011). Brasília, Denatran / Ministério das Cidades. Disponível em http://www.denatran.gov.br/frota.htm

Duarte, D. H. S. (2000). Padróes de ocupação do solo e microclimas urbanos na região de clima tropical continental brasileira. Tese Doutorado em Arquitetura, Faculdade de Arquitetura e Urbanismo da Universidade de São Paulo (faU-USP), São Paulo.

Duarte, D. H. S., Serra, G. G. (2003). Padröes de Ocupaçâo do Solo e Microclimas Urbanos na Regiāo de Clima Tropical Continental Brasileira: Correlaçóes e Proposta de um Indicador, Revista Ambiente Construído, v.3, n.2, p. 7-20, abril/junho 2003, Porto Alegre, Brasil, Associação Nacional de Tecnologia do Ambiente Construído (ANTAC).

Elkington, J. (1999, noviembre). Triple bottom line revolution: Reporting for the third millennium. Australian CPA, 69(10), 75-77.

Girardet, H. (1997). Sustainable Cities. A contradiction in terms? Architectural Design, 67(12), 8-13.

Instituto Brasileiro de Geografia e Estatística (IBge). (2008). Projeção da População do Brasil por Sexo e Idade Para O Período 1980-2050 - Revisáa 2008. Rio de Janeiro: ibge. Disponível em http://www.ibge.gov.br/home/estatistica/populacao/projecao_da_ populacao/2008/projecao.pdf

Instituto Brasileiro de Geografia e Estatística (IBGE). (2010). Resultados do Censo 2010. Disponível em http://www.ibge.gov.br/censo2010/resultados_do_censo2010.php. Acessado em: 31/01/2011.

Instituto de Pesquisa Econômica Aplicada (IPEA). (2008). Populaçáo e PIB das Cidades Médias crescem mais que no resto do Brasil. Disponível em: http://www.ipea.gov.br/sites/000/2/ pdf_release/32_release_PIBdascidades.pdf

Kennedy, C., Cuddihy, J. e Engel-Yan, J. (2007). The changing metabolism of cities. Journal of Industrial Ecology, 11(2), 43-59. doi: 10.1162/jie.2007.1107 
Leite, A. (2014). Custo da Copa no Brasil pode atingir os $\mathrm{R} \$ 30$ bilhóes. Jornal Estadão Conteúdo, São Paulo (SP), terça-feira, 4 de mar de 2014. Disponível em http://bit. ly/1slwUMh

Litman, T. A. (2002). The costs of automobile dependency and the benefits of balanced transportation. Victoria, BC, Canada: Victoria Transport Policy Institute. Disponível em http://www. vtpi.org/autodep.pdf

Maitelli, G. (1994). Abordagem tridimensional de clima urbano em área tropical continental: o exemplo de Cuiabá, MT. 1994. Tese Doutorado em Geografia - Faculdade de Filosofia, Letras e Ciências Humanas, Universidade de São Paulo, São Paulo.

Novotny, V. (2010). Water and energy footprints for sustainable communities. Paper presented at the Singapore International Water Week Conference, Water Practice \& Technology (conference proceedings) June 28-July 2, 2010. Diponível em http:// aquanovallc.com/wp-content/uploads/2010/12/Singapore-2010.pdf

Programa das Nações Unidas para o Desenvolvimento (pNUD). (2010). Relatório de Desenvolvimento Humano 2010 - A Verdadeira Riqueza das Naçóes: Vias para o Desenvolvimento Humano. New York: Communications Development Incorporated, Washington, D.C. Disponível em www.idis.org.br/biblioteca/pesquisas/pnud_ hdr_2010.pdf

Programa das Nações Unidas para o Desenvolvimento (PNUD). (2011). Relatório de Desenvolvimento Humano 2011 - Sustentabilidade e Equidade: Um Futuro Melhor para Todos. New York: Communications Development Incorporated, Washington D.c. Disponível em http://hdr.undp.org/en/reports/global/hdr2011/download/pt/

Rogers, R. \& Gumuchdjian, P. (2005). Cidades para um pequeno planeta. Barcelona: Gustavo Gili.

Romero, M.; Silva, G. J. A. da; Franca, S. F.; Silva, C. F.; Machado, A. C.; Cintra, M. S.; Bertoni, S.; Silva, F. A., Rocha, R. M. (2010). Urbanismo sustentável: A construção de indicadores para a avaliação da qualidade do espaço urbano no Distrito Federal, Brasil. Urbanismo Sustentável (Trabalho Final de Disciplina). Programa de Pós-Graduação, Faculdade de Arquitetura e Urbanismo, Universidade de Brasília (PPG-FAU-UnB), Brasília.

Rueda, S. P. (2002). Modelos de ordenación del territorio más sostenibles. Congreso Nacional de Medio Ambiente, Barcelona, noviembre. Disponível em http://www.conama.org/ documentos/1954.pdf

Santos, M. (2009). A urbanização brasileira (5a Ed., 2a Reimpr). São Paulo: Editora da Universidade de São Paulo (Edusp).

Silva, G. J. A. da (2010). Projeto de intervenção urbana: Uma ruptura de paradigmas. São Paulo: Editora Blucher.

Silva, G. J. A. da. (2011). Cidades sustentáveis: uma nova condição urbana. Estudo de Caso: Cuiabá, MT. Tese Doutorado em Arquitetura e Urbanismo). Programa de PósGraduação, Faculdade de Arquitetura e Urbanismo, Universidade de Brasília (PPG-FAUUnB), Brasília. Disponível em http://repositorio.bce.unb.br/handle/10482/11232

Silva, G. J. A. da, Romero, M. A. B. (2011a). O urbanismo sustentável no Brasil: A revisão de conceitos urbanos para o século xxI (parte 01). Arquitextos, 128.03. Disponível em http://www.vitruvius.com.br/revistas/read/arquitextos/11.128/3724 
Silva, G. J. A., Romero, M. A. B. (2011b). O urbanismo sustentável no Brasil: a revisão de conceitos urbanos para o século xxi (parte 02). Arquitextos, 129.08. Disponível em http://vitruvius.es/revistas/read/arquitextos/11.129/3499

Silva, G. J. A. et al (2010). A construção de indicadores para avaliação da qualidade do espaço urbano no Distrito Federal do Brasil. Paranoá: Cadernos de Arquitetura e Urbanismo, 9(5). Disponível em http://pluris2010.civil.uminho.pt/Actas/PDF/Paper276.pdf

un-Habitat. (2008). State of the World's Cities 2008/09: Harmonious Cities. London, uk: Earthscan.

Wolman, A. (1965). The metabolism of cities. Scientific American, 213(3),179-190, 